\title{
19. DIAGENESIS OF A SEAMOUNT OOLITE FROM THE WEST PACIFIC, LEG 20, DSDP
}

\author{
Reinhard Hesse, McGill University, Montreal, Canada
}

\section{SAMPLES AND LOCATION}

Leg 20 recovered the first oolite drilled during the Deep Sea Drilling Project. The oolitic limestone was brought up from 83 and 106 meters subbottom depth in Cores 3 and 4 of Hole 202 on Ita Matai Seamount. Drilling of the seamount was undertaken at the end of Leg 20 , when the poor state of repair of the drilling gear prohibited further drilling in deep water. Water depth at this site is 1515 meters. Thus Cores $3(45 \mathrm{~cm}$ recovery) and $4(35 \mathrm{~cm}$ recovery) come from a total depth of 1598 and 1621 meters, respectively. Ita Matai Seamount is located at the eastern margin of the Caroline Abyssal Plain (Figure 1). The location of Site 202 is $12^{\circ} 40.90^{\prime} \mathrm{N}, 156^{\circ} 57.15^{\prime} \mathrm{E}$.

\section{AGE}

Only a minimum age of the oolite can be determined which is earliest Eocene to Paleocene. The overlying foraminiferal ooze is mid-Eocene in Core 2 which occurs 9 meters above the highest oolite core. Early Eocene foraminifera and nannofossils occur in Hole 200A at the base of the pelagic carbonates. These carbonates overlie a strong seismic reflector that can be traced to Site 202 (Figures 2, $3)$, where it corresponds to the oolitic limestone. Subsidence of the seamount, resulting in drowning of its top, thus must have started before early Eocene. The oolite, therefore, must be older than early Eocene. Sparse bryozoan fragments in the oolite were not identifiable (E. Voigt, personal communication).

A closer age determination of the oolite would be desirable, for it would help to delimit the time of subsidence of the seamount below sea level and thus provide a more exact subsidence rate for the oceanic crust

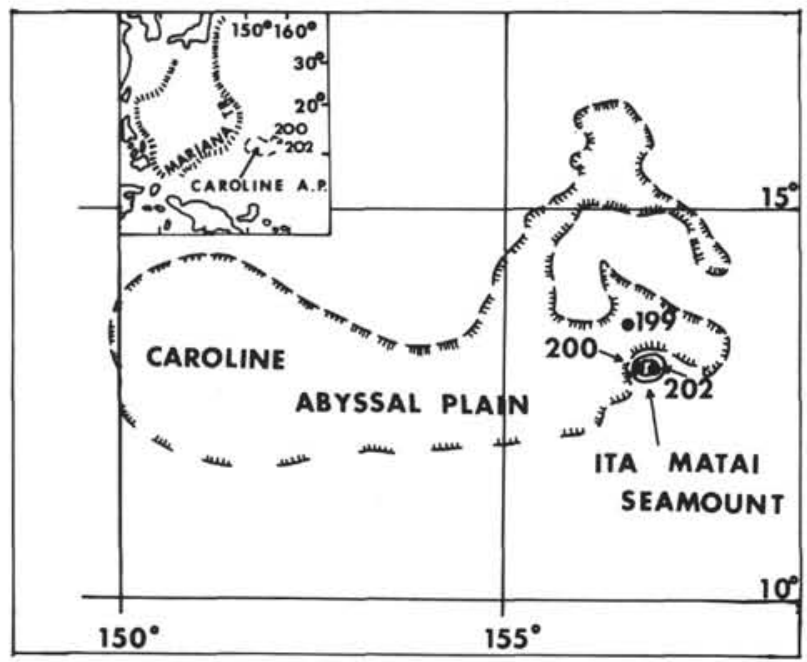

Figure 1. Location of Ita Matai Seamount. of the Caroline Abyssal Plain area. The present estimate of the average subsidence rate for the last 54 million years is $32 \mathrm{BuB}\left(32 \mathrm{~m} / 10^{6} \mathrm{y}\right)$ based on the above data. This is somewhat less than the figure taken from Sclater et al.'s (1971) general subsidence-rate curve for the north Pacific (about $40 \mathrm{~m} / 10^{6} \mathrm{y}$ for crust as old as early Eocene).

\section{COLOR, TEXTURE, AND POROSITY}

The oolite is of white yellowish to pale tan color except for the uppermost $10 \mathrm{~cm}$ of Core 3 , which displays shades of gray.

Individual ooids displaying a distinct nucleus range in size from 0.12 to $1.45 \mathrm{~mm}$ in diameter. Skeletal fragments associated with the ooids range up to $3 \mathrm{~mm}$. The sediment is a medium-grained calcareous sand (estimated mode between 0.35 and $0.5 \mathrm{~mm}$ ). Sample 5 , Core 3 is a coarse ooid sand.

Sorting is usually moderate $\left(\delta_{\mathrm{G}}=0.75-0.8\right)$, rarely moderately good $\left(\delta_{\mathrm{G}}=0.7\right)$. Poor sorting $\left(\delta_{\mathrm{G}}=1.4\right)$ was observed in the coarse sand of Sample 5, Core 3. Determinations are based on visual estimates in thin sections using the central $70 \%$ of the grain-size distribution, e.g., the "graphic standard deviation" $\delta_{\mathrm{G}}$ of Folk (1968).

The oolite is a lithified limestone with relatively high porosity, ranging from $10 \%$ to $15 \%$. Samples analyzed have about $20 \%$ porosity (Table 1 ). Most of this porosity is

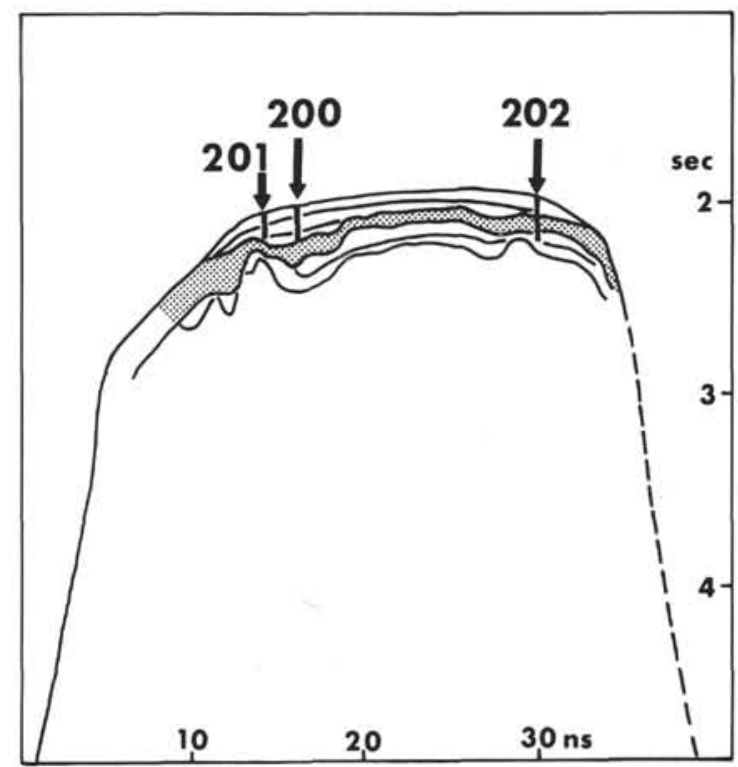

Figure 2. Drill sites on Ita Matai Seamount. Stippled: seismic reflector (i.e., oolite in Hole 202). Horizontal scale in nautical seconds. Distance between Sites 200 and 202 is about $20 \mathrm{~km}$. (Sketch after airgun profile by B. C. Heezen.) 
primary, due to incomplete cementation. Some of it $(0.7 \%$ to $1.3 \%$ ), however, is secondary, caused by internal solution.

\section{PETROGRAPHIC COMPOSITION}

Three groups of components may be distinguished: ooids, lithoclasts, and skeletal fragments. Ooids form the main constituent of the rock (between $50 \%$ and $70 \%$ ), and skeletal fragments may be as high as $13 \%$. Lithoclasts amount to less than $3 \%$. Cement occupies between $8 \%$ and $12 \%$ of the rock volume.

The size relationship between cortex and nucleus of the ooids may show all variations from very thin cortices coating large nuclei to thick cortices covering small nuclei. Nuclei are often provided by broken ooids and skeletal fragments, rarely by feldspar grains or basalt fragments.

The microstructure of the cortex displays either distinctly concentric light and darker laminae or a diffuse dark brown micrite with a nebulous radial arrangement of the cortex material. The ooids are recrystallized and reflect only relicts of original structure.

Skeletal fragments include mollusks (bivalves and gastropods), coralline algae, echinoderms, bryozoans, and foraminifera in this order of abundance. Most of the fragments display a micritic rim either resulting from micritization

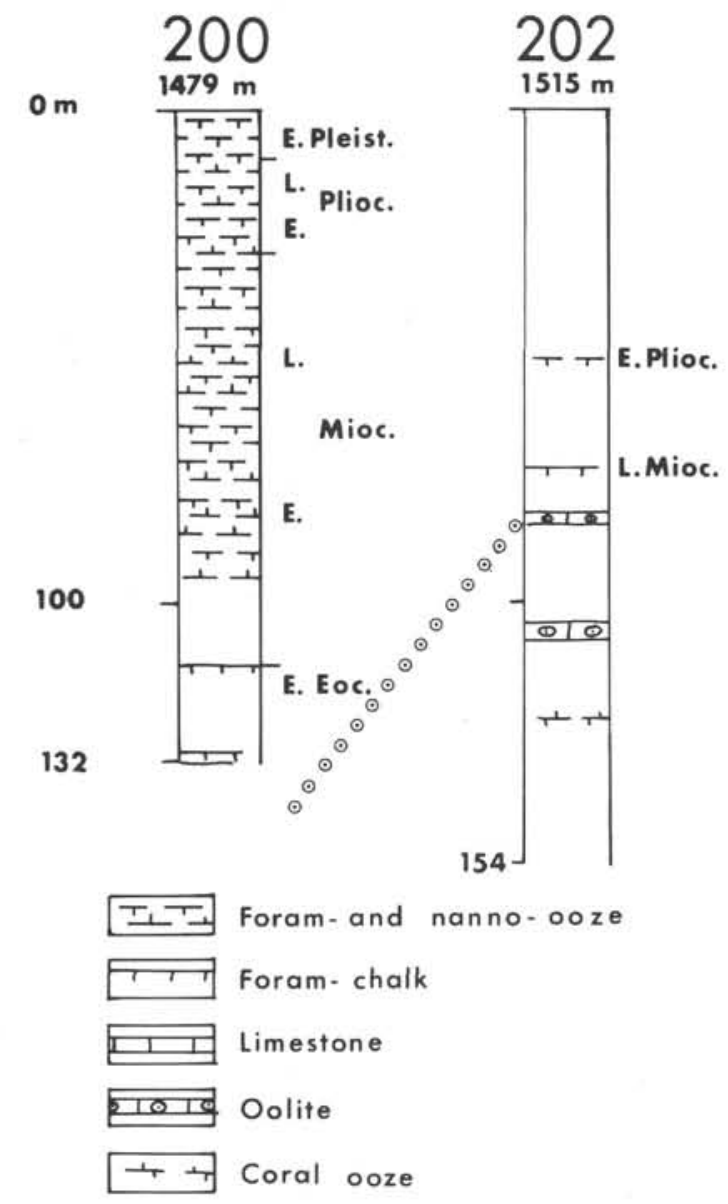

Figure 3. Stratigraphy of Sites 200 and 202. caused by boring algae (irregular boundary between rim and grain, distinctly visible borings) or by precipitation of cryptocrystalline carbonate as ooidic coatings (displaying faint concentric laminations). Some of the echinoderm fragments lack the micritic rim, which is a prerequisite for the development of syntaxial calcite overgrowth (see below).

Lithoclasts include rare oolitic limestone fragments derived intraformationally or from older oolites (which is more likely since they are completely cemented) and basalt fragments which show a thin micritic carbonate coating ( 30 to $50 \mu$ in thickness).

\section{MINERALOGIC AND CHEMICAL COMPOSITION}

The dominant calcium carbonate phase is lowmagnesium calcite on the basis of X-ray diffraction analysis of ground bulk samples (3.04 $\AA$ peak for (1014) in slow scans; $1 / 8^{\circ}(2 \theta) /$ min using $\mathrm{CuK} \alpha$ radiation), by staining tests and microprobe analyses of selected grains. After treatment with Feigl's solution (Feigl, 1954, p. 469), only a very few ooids retained a dark stain (on isolated laminae) indicative of aragonite.

Microprobe analyses of a few selected echinoderm and algal fragments showed the absence of any significant amounts of magnesium as well as strontium in the grains and the rim cement of the echinoderms. Some of the ooids in Sample 5, Core 3 show single brownish laminae of clear, radially aligned calcite. Individual brown spots less than $5 \mu$ in diameter, which occur along the track of the clear laminae, are relatively high in iron. The iron content along the lamina is lower than the brown spots, but higher than in adjacent laminae. The spots are probably limonite. The larger grains which contain a brownish lamina usually contain only one such lamina, located somewhere midway between the outer margin of the nucleus and the outer margin of the cortex.

Sulfur, which was analyzed concurrently with iron, was always higher in the ooids than in the background of the impregnating resin. It is probably present in the organic matter retained in the ooids.

\section{ULTRASTRUCTURE AND ORIGIN OF OOIDS- CURRENT OBSERVATIONS AND HYPOTHESES}

Study of the ultrastructure of the cortices of modern ooids by Purser et al. (1971) revealed the presence of two types of ooids related to the environment of ooid formation. Ooids of high energy environments (tidal flats, coastal bars, and beaches) of the Persian Gulf display two primary ultrastructures in their cortices: laminae of tightly packed anhedral nannocrystals of aragonitic measuring $0.25 \mu$ in diameter and lacking preferential orientation. They are interbedded with porous, felted laminae of elongate nannocrystals of aragonite measuring $0.25 \mu$ in diameter and 1 to $1.5 \mu$ in length. These euhedral (needles) and subhedral crystals (rods with slightly rounded edges) are oriented statistically tangential with respect to the nucleus. Modern Bahamian ooids (Loreau, 1970) and sub-Recent occurrences of the Mediterranean (Fabricius and Klingele, 1970) are of this type. 
TABLE 1

Petrographic Composition of Ita Matai Oolite (in per cent; Point-Counter Analyses)

\begin{tabular}{ccccccccc}
\hline \multicolumn{1}{c}{$\begin{array}{c}\text { Subbottom } \\
\text { Depth } \\
(\mathrm{m})\end{array}$} & $\begin{array}{c}\text { Number } \\
\text { of Points } \\
\text { Counted }\end{array}$ & Ooids & $\begin{array}{c}\text { Skeletal } \\
\text { Fragments }\end{array}$ & Lithoclasts & $\begin{array}{c}\text { Internal } \\
\text { Cement }\end{array}$ & $\begin{array}{c}\text { External } \\
\text { Cement }\end{array}$ & $\begin{array}{c}\text { Pore } \\
\text { Space }\end{array}$ \\
\hline $202-5,3 C \mathrm{CC}$ & 83 & 898 & 69 & 3 & 0.5 & 0.5 & 8.0 & 19 \\
$202-8,3 \mathrm{CC}$ & 83 & 896 & 65.5 & 3 & 1.5 & 2.5 & 8.5 & 19 \\
$204-1,4 \mathrm{CC}$ & 105.5 & 599 & 51 & 13 & 3.0 & 5.0 & 7.0 & 21 \\
$202-2,4 \mathrm{CC}$ & 105.5 & 895 & 66 & 6 & 0.5 & 1.0 & 6.5 & 20 \\
\hline
\end{tabular}

Low energy ooids, which may grow up to $5 \mathrm{~mm}$ in size and display somewhat irregular shapes, occur on evaporitic tidal flats of the Persian Gulf. Their cortex consists of an alternation of tightly packed nannograins lacking preferential orientation with laminae of aragonite prisms that are oriented radially. Crystal size in the radial laminae is 1 by 3 to $5 \mu$. Low energy ooids forming in hypersaline environments of the Persian Gulf appear to be similar in their ultrastructure to ooids described from Great Salt Lake, Utah (Fabricius and Klingele, 1970).

Origin of the needles is thought to result from physicochemical precipitation mainly by homogeneous nucleation in environments poor in or lacking organic matter, whereas the anhedral nannocrystals (earlier called cryptocrystalline) form where nuclei originated in contact with or within organic matter (Loreau, 1971). As mechanisms for the genesis of these anhedral nannocrystals, Loreau envisages "heterogenous nucleation due to abundant impurities" and "crystal growth limited by the great number of evenly distributed nuclei which mutually interfere." This process is held responsible by Loreau for the development of micrite in ooids and also for the development of micritic coatings on skeletal fragments. Micrite formation of this type would be a primary feature due to the omnipresence of mucilagenous organic matrix on grain surfaces.

This process offers an interesting alternative to the generally accepted formation of micritic envelopes by boring algae (Bathurst, 1966). The presence of endolithic blue-green algae in ooid cortices has been known for a long time (Rothpletz, 1892). The effects of their boring action in ooids were most clearly shown by Margolis and Rex (1971) in a study using the scanning electron microscope. Precipitation of nannocrystals of aragonite in the boring tubes may be directly related to the presence of organic mucilage secreted by the boring organisms. The amino-acid composition of algae (blue and bluegreen) and the ooid coatings is similar (Trichet, 1968; Mitterer, 1968).

Micrite originally precipitating on the organic mucilage coating of the entire ooid surface should display concentric laminations. The importance of organic coatings for the inorganic precipitation of aragonite on ooids was emphasized by Suess and Fütterer (1972). These authors used humic acid solutions extracted from modern sediments in their experiments to produce aragonitic ooids. Humic acids, which in seawater occur as intermediate stage between dissolved and particulate organic matter, are released by brown or red algae and might occasionally be found in environments of present-day ooid formation in concentrations sufficient for aragonite precipitation. Proteins and polypeptides may have the same effect.

\section{ORIGIN OF ITA MATAI OOLITE}

In Ita Matai, oolite micritization of the cortices is partly due to the action of boring algae as clearly shown by the presence of individual tubes of microborings (Plate 1, Figures 1 and 2), which have not been obliterated by diagenesis. Micritization of this type may coincide or alternate with another process of micrite formation, i.e., the primary precipitation of laminae of anhedral nanno crystals (micrite) on the entire ooid surface as suggested by the common occurrence of distinct micritic laminae of constant thickness. Whether the latter process is indirectly also related to the presence of microborers (algae, fungi) and bacteria (?) secreting organic mucilage or is merely controlled by the (inorganic) precipitation of organic matter from seawater on the ooid surface remains to be shown.

The lack of preservation of the original composition and ultrastructure of the grains precludes a consideration of the possible presence of radially oriented aragonite. The absence of grains larger than $1.5 \mathrm{~mm}$ in diameter and lack of irregularly shaped grain surfaces (other than mechanically abraded surfaces) suggests that Ita Matai oolite is of the high energy type.

There is, however, one exception. The poorly sorted oolite of Sample 5, Core 3, which contains the largest individual ooids observed in Ita Matai oolite, displays grains with irregularly shaped surfaces (Plate 3 , Figures 1 to 6). The larger grains often contain protrusions formed by encrusting algae and their sporangia subsequently coated by a micrite layer of algae origin? The protrusions may form bumps or horns (Plate 9, Figures 5, 6). Rarely do they occur within the inner portions of the cortex. Irregularities of this type are generally lacking in grains smaller than 1 $\mathrm{mm}$ in diameter. Micritization of the cortex is pronounced in this sample. Laminae of clear radial calcite (see next paragraph) are restricted more or less to the inner portions of the cortices.

These irregular shapes suggest that at a late stage of ooid growth, the deposit was removed from the agitated high energy zone and attained features characteristic of ooids forming in "quiet water" or low energy environments. They are in part micro-oncoids (outer portion of the cortex) and thus resemble ooids from Laguna Madre (Freman, 1962) or "pelagic oolites" described by Jenkins (1972). In contrast to the Jurassic oolites of Sicily (Jenkins, op. cit.), however, no coccoliths have been found incorporated into the cortices. Since Sample 5 comes from $20 \mathrm{~cm}$ below the top of Core 3 (which probably is the top of the oolite), removal from the high energy zone may indicate beginning of subsidence. The grains may have obtained their final shape 
in water somewhat deeper than typical for the formation of modern high energy ooids.

\section{DIAGENESIS}

Diagenetic alteration of Ita Matai oolite (Figure 4) includes the following features, which in part may have formed concurrently rather than subsequently: (1) Replacement of the cortex aragonite in ooids by low magnesian calcite; (2) Internal dissolution of the nonmicritized skeletal aragonite leading to a cavity stage; (3) Conversion of skeletal high-magnesian to low-magnesian calcite; (4) Syntaxial overgrowth on echinoderm fragments; (5) Internal cementation and crystallization of external sparry rim cement.

\section{Replacement of Cortex Aragonite in Ooids by Low- Magnesian Calcite (Process 1)}

The original aragonite of the ooids is replaced by low-magnesian calcite except for a few single laminae. The calcite occurs either as elongated crystals up to $5 \mu$ long and $1 \mu$ wide or as subsequant or irregularly shaped nanno crystals up to $5 \mu$ in diameter (Plates 4 to 6). The elongated crystals are arranged radially with respect to the nucleus (Plate 4). Under crossed nicols clear laminae of radial calcite are optically negative, whereas in original aragonitic ooids the clear laminae are optically positive due to the preferred tangential orientation of the aragonite needles. Likely, the clear laminae of radial calcite represent a replacement of the tangentially oriented aragonite needles. Laminae or areas of subsequant calcite nanno-crystals (Plate $5)$, on the other hand, may correspond to the organic matter-rich areas of original anhedral nannocrystals of aragonite.

The transition from tangential aragonite to radial calcite was explained by Shearman et al. (1970) as a solution-

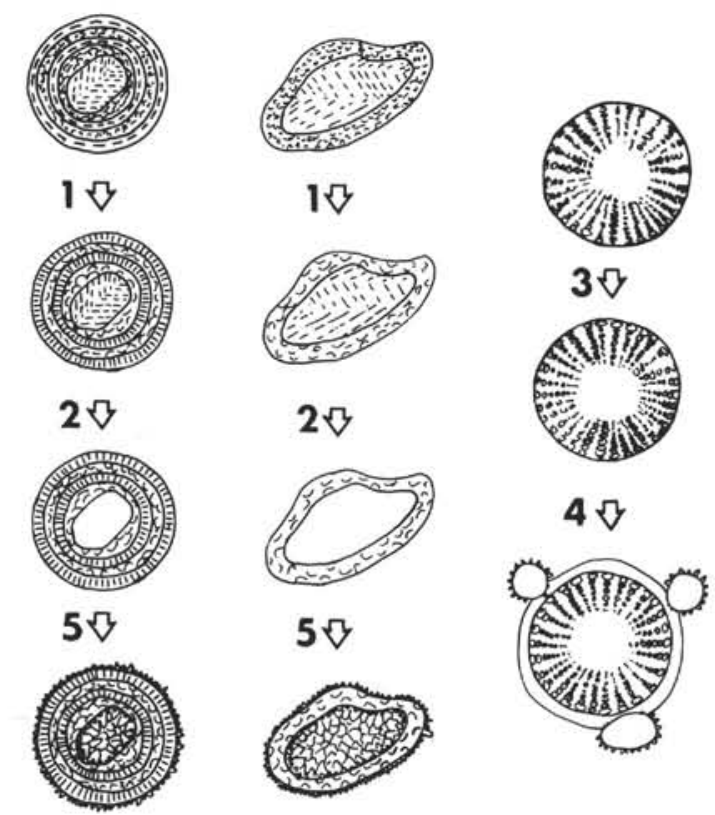

Figure 4. Diagrammatic representation of diagenetic processes in Ita Matai oolite. precipitation process occurring within the framework of concentric laminae of organic mucilage. During this process the delicate mucilage framework of the ooid cortex apparently remains intact while the aragonite dissolves and the calcite precipitates. To avoid collapse of this framework the process must proceed on a piecemeal basis. The concentric lamellae of organic matter seem to serve as a substratum perpendicular to and between which the newly forming calcite grows. The radially arranged calcite crystals are not truly euhedral, but display rather serrated crystal boundaries (Plate 4) suggesting that either nucleation was very rapid or that the development of the crystal shape was influenced by the presence of organic matter remaining between the main organic laminae. As suggested by Shearman et al. (op. cit.) such organic matter would be pushed aside during the growth of the calcite thus giving rise to radially oriented microwedges of organic matter visible in diagenetically altered ooid cortices. (Plate 1, Figures 1 and 2). The data from pre-Eocene ooids from Ita Matai Seamount are in accordance with the hypothesis of Shearman et al. (1970). Furthermore, the original difference in concentration of organic matter in the various laminae which seems to be responsible for the development of either "cryptocrystalline" (organic matter-rich lamellae) or tangentially oriented aragonite (organic matter-poor lamellae) appears to still control the distribution of laminae (or areas) of anhedral calcitic nannocrystals and laminae of clear radial calcitic nannocrystals.

The replacement of aragonite by calcite is significantly accelerated in the presence of basic and neutral amino acids, as pointed out by Jackson and Bischoff (1971). Modern ooids are enriched in acidic amino acids (Mitterer, 1968). One might speculate that the change from aragonite to calcite might be preceded by a change in the amino acid composition. This, however, seems not to be the case as shown by Trichet's (1968) analyses of Jurassic oolites, which still show a predominance of acidic amino acids.

The micritic envelopes of skeletal and other fragments probably transform concomitantly with the change from aragonite to low-magnesian calcite in the ooid cortex. Micritic envelopes may originally consist of either aragonite or high-magnesian calcite (Bathurst, 1971). They have a high content of organic matter similar to that of ooid cortices. The conversion from aragonite to low-magnesian calcite in the micritic rim may thus be similar to the dissolution-precipitation process assumed for the cryptocrystalline laminae in ooids. Whether micritic envelopes consisting of high-magnesian calcite transform to lowmagnesian calcite in the same way is not known.

The replacement of aragonite by low-magnesian calcite is assumed to be the first step in the diagenetic alteration of Ita Matai oolite. Internal dissolution of skeletal aragonite in the nuclei could not have taken place before the aragonite to calcite transformation because it would have led to grain collapse in cases where the micrite rims are thin. This has not been observed.

\section{Internal Dissolution of Skeletal Aragonite Leading to a Cavity Stage (Process 2 )}

Many grains display evidence for internal dissolution of skeletal aragonite within micritic envelopes. The cavities are 
still open, at least in part, where subsequent internal cementation by sparry calcite (see Process 5) did not proceed to completion. Observation of this feature with the scanning electron microscope (Plates 4 and 6) precludes the possibility that these cavities might have been produced mainly in the process of preparing the thin section (some cavities certainly have or have been enlarged at this stage). In some grains parts of the skeletal fragments escaped dissolution. They are cemented by sparry calcite, and together with the cement, are enclosed in the micritic envelope.

\section{Conversion of Skeletal High-Magnesian to Low Magnesian Calcite (Process 3)}

The relative abundance of echinoderms and coralline algae among the skeletal fragments suggests that dissolution of high-magnesian calcite followed by a cavity stage did not occur or was only minor.

Skeletal fragments of echinoderms and coralline algae, however, have lost their original magnesium and strontium content. The recrystallization process does not obliterate the original internal structure, which is preserved in minute detail.

\section{Syntaxial Overgrowth on Echinoderm Fragments (Process 4)}

Syntaxial rim cement of echinoderm fragments may grow concurrently with the sparry calcite cement (described below), but at faster growth rates as seen at grain contacts (Plate 8). Where adjacent grains are partially enclosed in the syntaxial rim cement of the echinoderm fragments, the thin rim of sparry cement normally fringing these grains is absent or is very small closest to the echinoderm fragment and attains its normal size outside the echinoderm overgrowth. Since the sparry external cement probably formed concurrently with the internal cement which follows internal aragonite dissolution, echinoderm overgrowths appear to follow Processes 1 to 3 described above. This is the simplest sequence of events to be proposed, although it must not necessarily be the one which actually occurred. In this case the low-magnesian calcite of the echinoderm overgrowth would precipitate as such on an already altered echinoderm calcite.

Syntaxial rim cement is absent on echinoderm fragments where these are coated by a micritic envelope. Surprisingly, however, most of the fragments appear no to be coated and can easily be detected in thin section by the presence of the relatively broad rim (up to $120 \mu$ thick on spines cut perpendicular to the $\mathrm{C}$-axis) of clear, single-crystal overgrowth. The early appearance of this syntaxial overgrowth on echinoderm fragments has been noted for ancient limestones (Evamy and Shearman, 1965; 1969).

\section{Crystallization of Sparry Rim Cement and Internal Cementation (Process 5)}

Cementation of this oolite has not proceeded beyond a first generation of calcite cement. It consists of a thin fringe of euhedral to subhedral low-magnesian calcite crystals on framework grains (external or intergranular cement). These crystals form essentially a one-crystal-thick layer on the rock components. Individual crystals commonly measure
10 to $30 \mu$ in length, but may occasionally be as long as $200 \mu$.

The sparry, void-filling cement (internal or intragranular) also belongs to this generation, although its time relationship to the fringing external rim cement could not be determined exactly due to the lack of broken grains among the internally dissolved grains. Grain size of this internal cement increases away from the micritic envelope. Internal cementation of dissolved grains has progressed considerably in comparison to the external cementation. Many grains are completely cemented. This may be due the chemical microenvironment being created within the cavity during and after aragonite dissolution Since this type of cement requires preceding dissolution of aragonite and since there seems to be no major time gap between this internal sparry cement and the external sparry cement, it seems likely that cementation in Ita Matai oolite follows both the aragonite dissolution and possibly also the high- to low-magnesian calcite transformation.

Since there is no distinct evidence for subaerial exposure (absence of meniscus cement, [?] early fibrous cements, etc.), diagenetic alternations in Ita Matai oolite have probably taken place in the subsurface below sea level.

\section{SUMMARY}

A pre-Eocene oolitic limestone was recovered from Ita Matai Seamount at the eastern end of the Caroline Abyssal Plain. The oolite is probably between 20 and 30 meters thick. Two cores were received from 83 and 106 meters subbottom depth, respectively (1598 and 1621 meters total depth). The moderately sorted carbonate sand consists mainly of ooids with admixtures of skeletal fragments and minor amounts of lithoclasts (oolite and basalt fragments).

Five different processes may be distinguished in the diagenetic alteration of the rock: (1) Replacement of aragonite in the ooid cortices and micrite envelopes by low-magnesian calcite, (2) Cavity development due to internal dissolution of nonmicritized skeletal aragonite; (3) Conversion of skeletal high-magnesian calcite to lowmagnesian calcite; (4) Syntaxial overgrowth of lowmagnesian calcite on echinoderm fragments; (5) Internal (intragranular) cementation and development of external (intergranular) sparry rim cement. Processes 1,2 , and 3 preceded Processes 4 and 5. No evidence for subaerial exposure was found.

Ita Matai Seamount subsided below sea level in pre-early Eocene time. Subsidence took place at an estimated maximum average rate of 32 meters per million years. For its pre-Eocene age the oolite is remarkably little cemented.

This report is based on a limited number of samples only. Conclusions are tentative and await corroboration as further samples become available.

\section{ACKNOWLEDGMENTS}

Thanks are due to U. Kapp, L. Larson, P. Leet, Dr. E. W. Mountjoy, M. Preda, and Dr. D. Sheeran of McGill University for various kinds of assistance. Miss U. Kapp provided technical assistance, Miss $P$. Leet typed the manuscript, L. Larson assisted with the microprobe analyses, M. Preda ran the X-ray diffraction analyses, and D. Sheeran introduced the author to the use of the scanning electron microscope. E. W. Mountjoy critically read the 
manuscript and suggested improvements. Financial aid for the preparation of this report was provided by National Research Council of Canada Grand No. A7368.

\section{REFERENCES}

Bathurst, R. G. C., 1966. Boring algae, micrite envelopes and lithification of molluscan biosparites: Geol. J., V. 5, p. 15-32.

, 1971. Carbonate sediments and their diagenesis. In Developments in sedimentology Vol. 12: AmsterdamLondon-New York (Elsevier).

Evamy, B. D. and Shearman, D. J., 1965. The development of overgrowths from echinoderm fragments: Sedimentology, V. 5, p. 211-233. , 1969. Early stages in development of overgrowths on echinoderm fragments in limestones: Sedimentology, V. 12, p. 317-322.

Fabricius, F. and Klingele, H., 1970. Ultrastrukturen von ooiden und oolithen: Zur genese and diagenese quartärer Flachwasserkarbonate des Mittelmeeres: Ver. Geol. B.-A. Wien, 1970(4), p. 594-617.

Feigl, F., 1954. Spot tests. Amsterdam-London-New York (Elsevier).

Folk, R. L., 1968. Petrology of sedimentary rocks: Austin, Texas, (Hemphill's).

Freeman, T., 1962. Quiet water oolites from Laguna Madre, Texas: J. Sediment. Petrol., V. 32, p. 475-483.

Jackson, T. A. and Bischoff, J. L., 1971. The influence of amino acids on the kinetics of the recrystallization of aragonite to calcite. J. Geol. V. 79, p. 493-497.

Jenkins, H. C., 1972. Pelagic "oolites" from the Tethyan Jurassic. J. Geol. V. 80, p. 21-33.

Kahle, C. F., 1965. Strontium in oolitic limestones: J. Sediment. Petrol. V. 35, p. 846-856.

Loreau, J. P., 1970. Ultrastructure de la phase carbonatee des oolithes marines actuelles: Compt. Rend. Acad. Sci. Paris, Ser. D, V. 271, p. 816-819.
1971. Ultrastructure, nucleation and crystal growth of natural and experimentally produced aragonite in relation to non-skeletal organic matter (Abstr. Progr.); Eighth Int. Sedimentol. Congr., p. 60, Heidelberg.

Margolis, S. V. and Rex, R. W., 1971. Endolithic algae and micrite envelope formation in Bahamian oolites as revealed by scanning microscopy: Geol. Soc. Am. Bull., V. 82, p. $843-852$.

Mitterer, R. M., 1968. Amino acid composition of organic matrix in calcareous oolites: Science V. 82, p. 843-852.

Newell, N. D., Purdy, E. G., and Imbrie, J., 1960. Bahamian oolitic sand: J. Geol., v. 68 , p. 481-497.

Purser, B. H., Loreau, J. P., and Shinn, E. A., 1971. Distribution and ultrastructure of the Holocene ooids of the Persian Gulf (Abstr. Progr.): Int. Sedimentol. Congr., 8th, Heidelberg, p. 80.

Rothpletz, A., 1892. On the formation of oolite: Am. Geol., v. 10, p. 279-282.

Schroeder, J. H., 1969. Experimental dissolution of calcium, magnesium, and strontium from Recent biogenic carbonates: a model of diagenesis: J. Sediment. Petrol., v. 39 , p. $1057-1073$.

Sclater, J. G., Anderson, R. N., and Bell, L. M., 1971. Elevation of ridges and evolution of the eastern central Pacific: J. Geophys. Res., v. 76, p. 7888-7915.

Shearman, D. J., Twyman, J., and Zand Karami, N., 1970. The genesis and diagenesis of oolites: Geol. Assoc. Proc., v. 81, p. $561-575$.

Seuss, E. and Fütterer, D., 1972. Aragonitic ooids: experimental precipitation from seqwater in the presence of humic acid: Sedimentology, v. 19, p. 129-139.

Trichet, J., 1968. Etude de la composition de la fraction organique des oolites. Comparison avec celle de membranes des bacteries et de cyanophycees: Compt. Rend. Acad. Sci. Paris, Ser. D, v. 267, p. 1492-1494. 



\section{PLATE 1}

Figure 1 Concentrically laminated cortex of ooid. Laminae consisting of radially arranged calcite prevail. Adjacent laminae separated by thin (dark) lamellae of organic matter. Elongate nannocrystals of calcite in the radial laminae appear to be separated from each other by radially oriented wedges of organic matter. Outer laminae are truncated at top of grain. Truncation surface is heavily bored by microborers producing micrite. Elsewhere in the cortex, micritization is more or less restricted to distinct patches along some laminae except at the right-hand side and close to the nucleus. In the interior part closer to the nucleus, micritization leads to a nebulous radial structure. This is seen in many cases where micritization has affected distinct portions of a grain.

Figure 2 Crossed nicols (Length of bar is $100 \mu$ ).

Figure 3 Intensely micritized ooid cortex. Original lamination is only faintly preserved at lower margin of photo. Distinct boring tubes appear on right-hand side of nucleus.

Figure 4 Crossed nicols (length of bar is $100 \mu$ ).

Figure 5 Internal dissolution of ooid followed by internal cementation. Internal cementation is not complete (see voids left on Fig. 6). It is, however, much more extensive than external cementation.

Figure 6 Crossed nicols (length of bar is $100 \mu$ ). 
PLATE 1

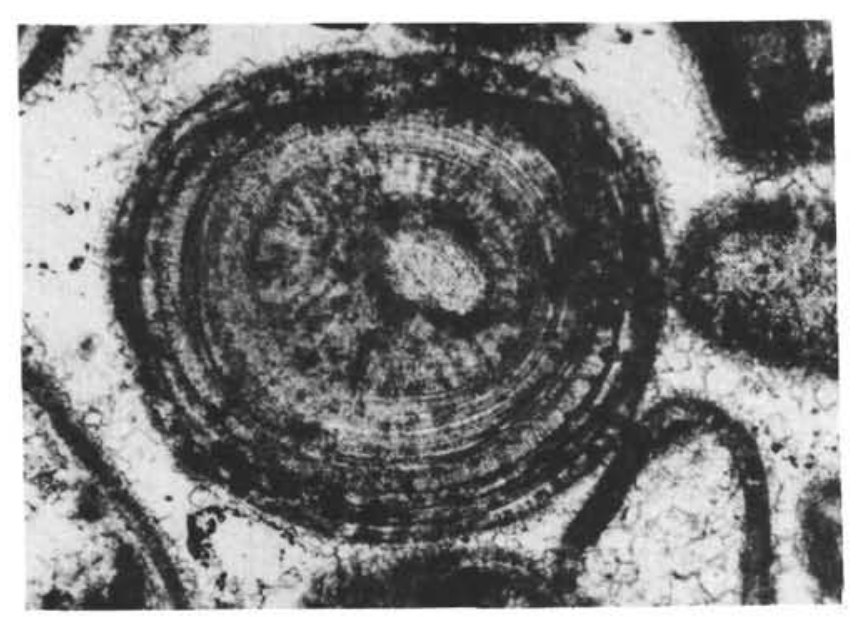

1

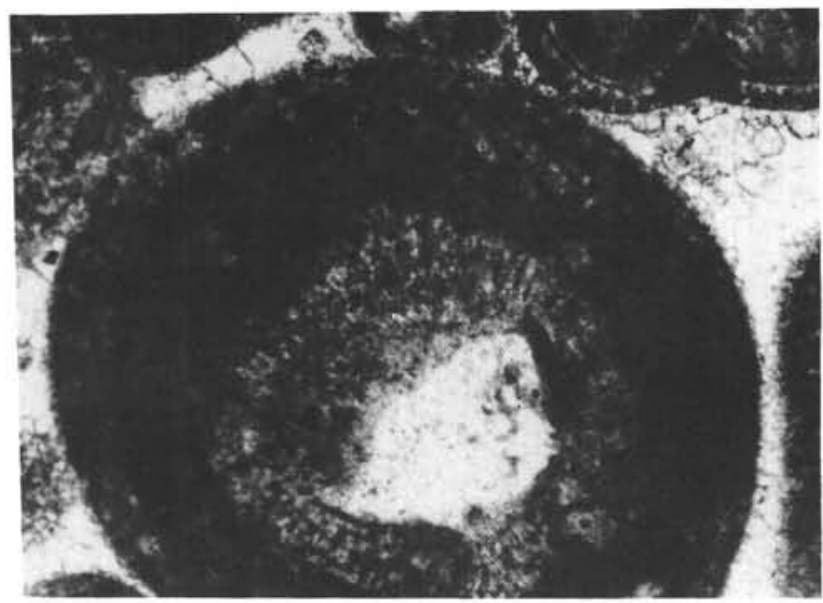

3

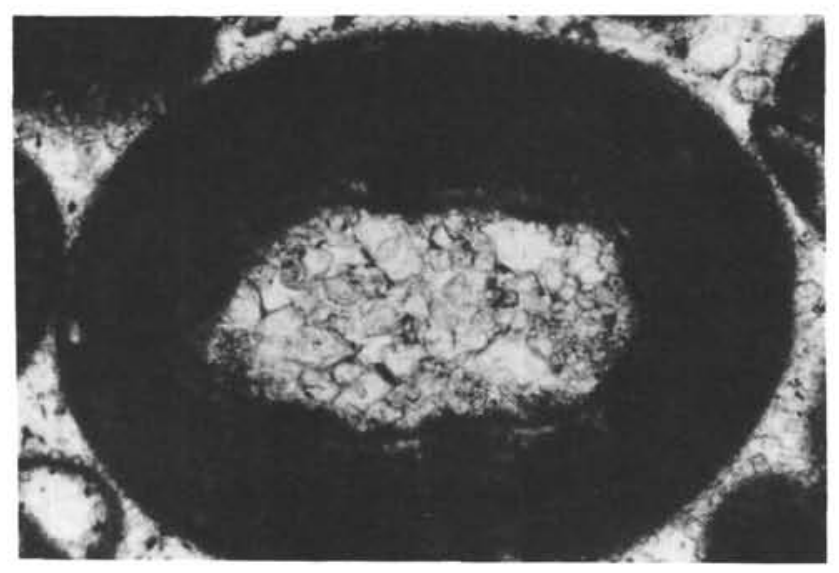

5

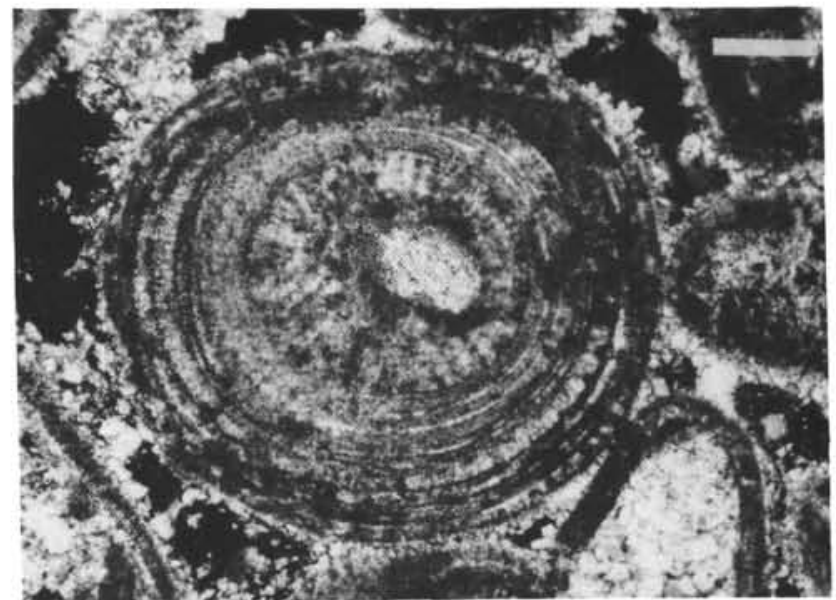

\section{2}

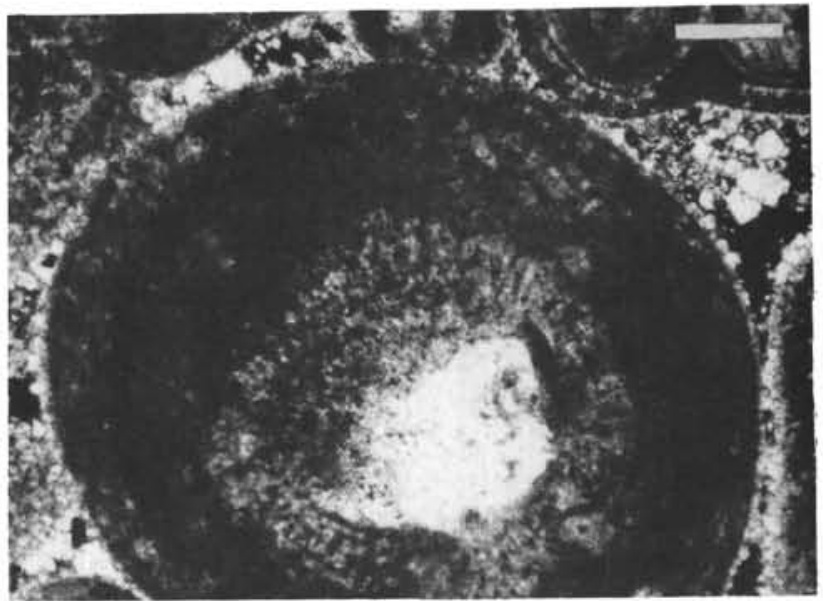

4

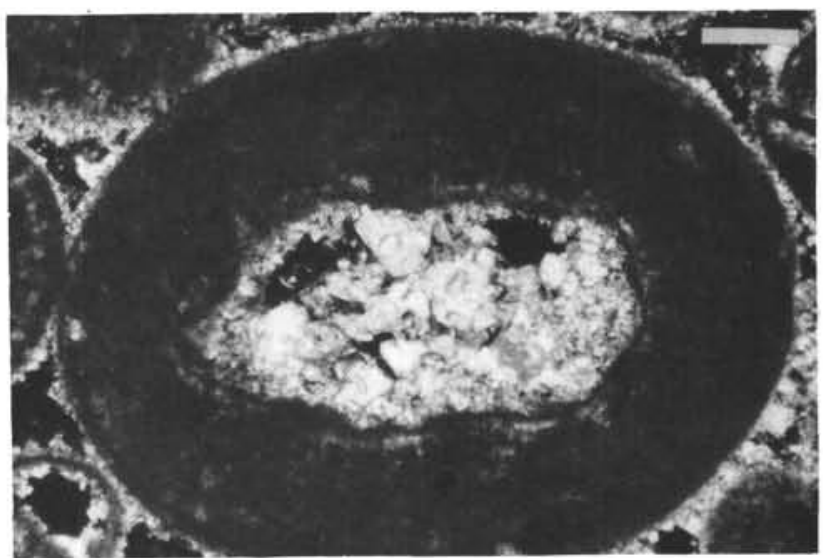

6 


\section{PLATE 2}

Figure $1 \quad$ Broken ooid fragment. Fracture surface slightly micritized and covered with a few newly deposited laminae. Patchy micritization (by microborers?) of outer broad lamina of radial calcite. Outermost micritic lamina seems to fall off. Clear calcite beneath it is radially oriented. Irregular outer surface, therefore, seems to be due to abrasion. Note thin external rim of sparry calcite cement. At contact with grain in upper left corner, cement displays meniscus-like appearance. No other miniscus cement was observed.

Figure 2 Crossed nicols (length of bar is $100 \mu$ ).

Figure 3 Ooid fragment broken twice serving as nucleus. Small micrite zone on each of the fracture surfaces. Internally cemented grain to the left-hand side. Internal cementation of this grain is nearly complete (see Fig. 4).

Figure 4 Crossed nicols (length of bar is $100 \mu$ ).

Figure $5 \quad$ Micritic grain with acute protrusions on outer margin probably enveloping algal sporangia. Ooid to the left with bored nucleus.

Figure 6 Crossed nicols (length of bar is $250 \mu$ ). 
PLATE 2
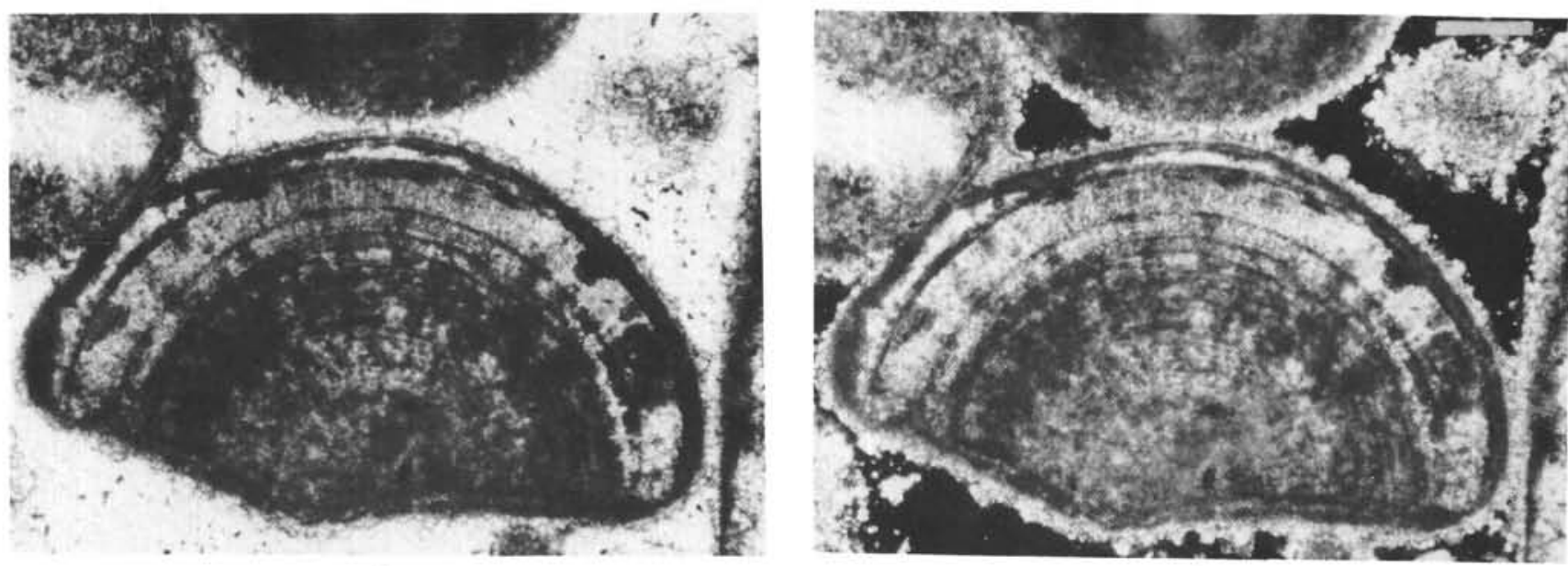

2

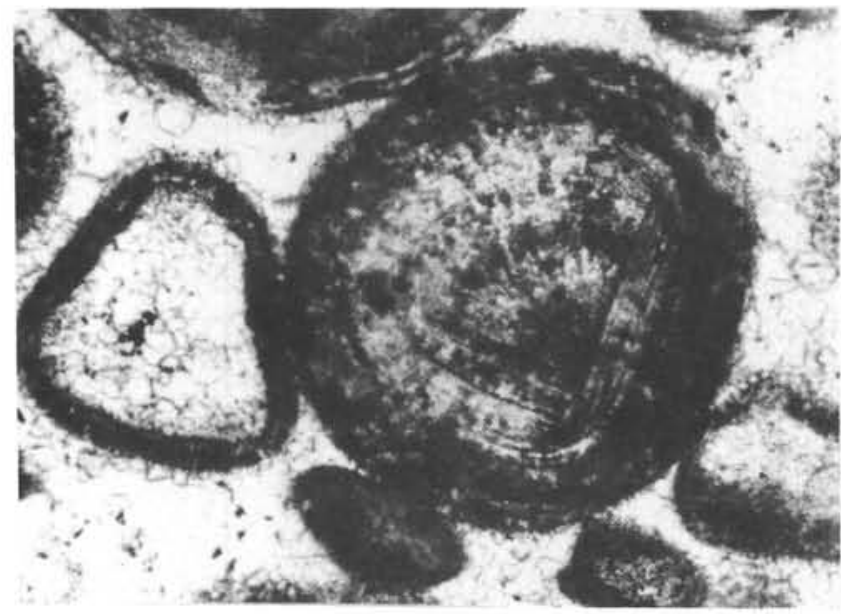

3

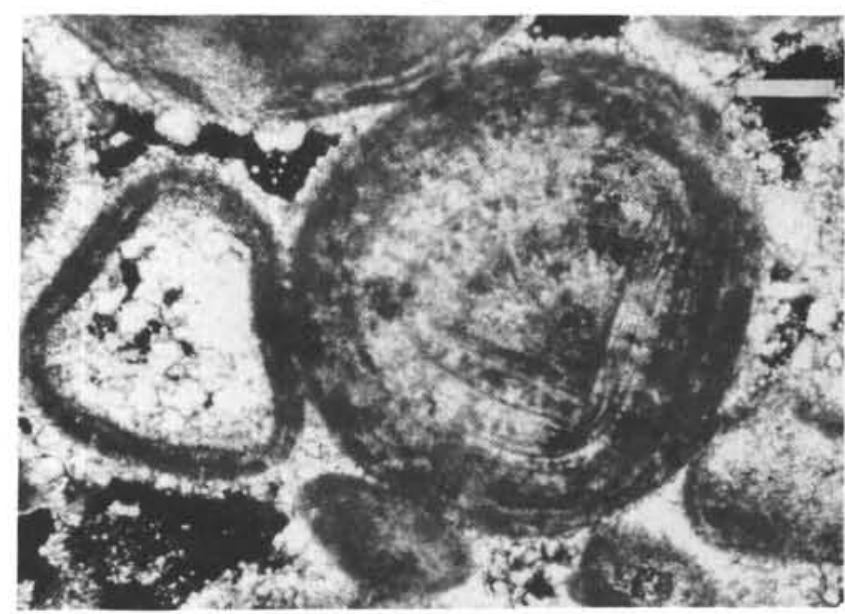

\section{4}

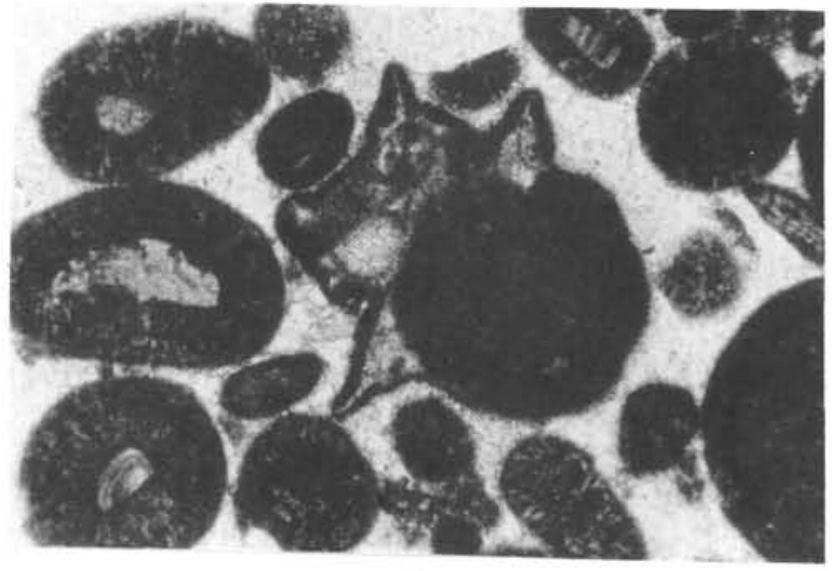

5

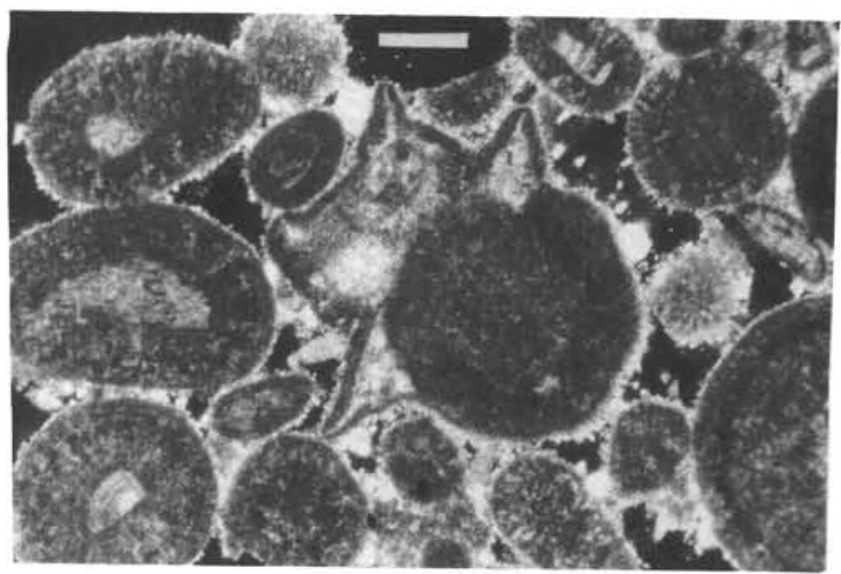




\section{PLATE 3}

Encrusting algae on outer cortices of ooids, Sample 5, Core 3. These seem to be more or less restricted to the top layers of the deposit and may indicate removal from the high energy zone (by beginning subsidence).

Figure $1 \quad$ Protrusion in outer cortex caused by algal structure which is covered by micritic laminae. (Fracture at right-hand margin of grain is artificial.)

Figure 2 Crossed nicols (length of bar is $100 \mu$ ).

Figure 3 Algal sporangia in outer ooid cortex. Nucleus formed by acute-angled ooid fragment displaying distinct dark and light laminae.

Figure 4 Crossed nicols (length of bar is $250 \mu$ ).

Figure $5 \quad$ Close-up of Figure 3.

Figure 6 Close-up of Figure 4 (length of bar is $100 \mu$ ). 
PLATE 3
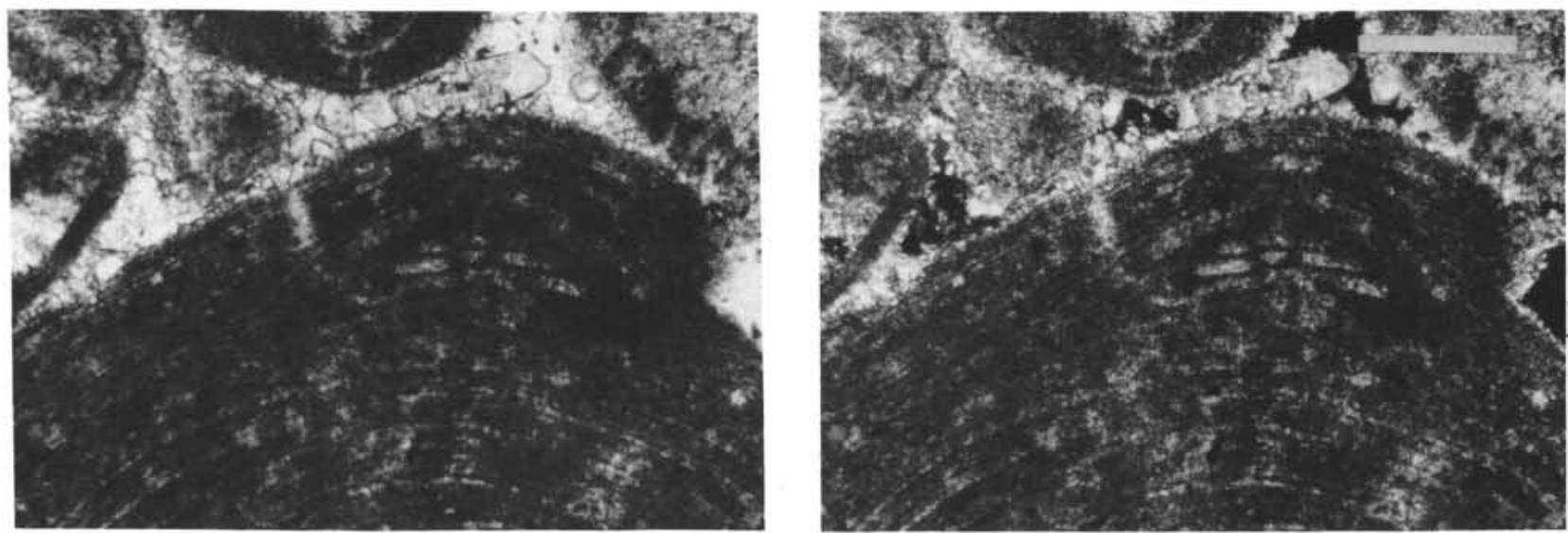

\section{1}

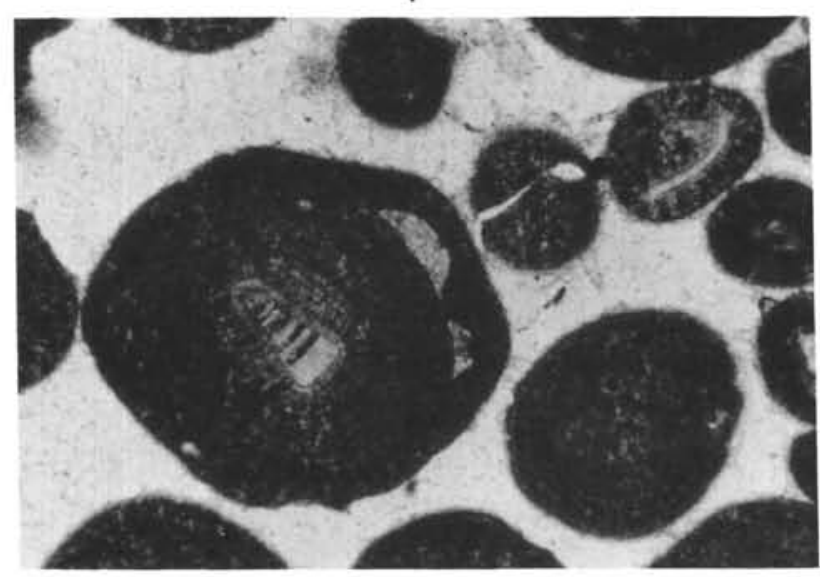

3
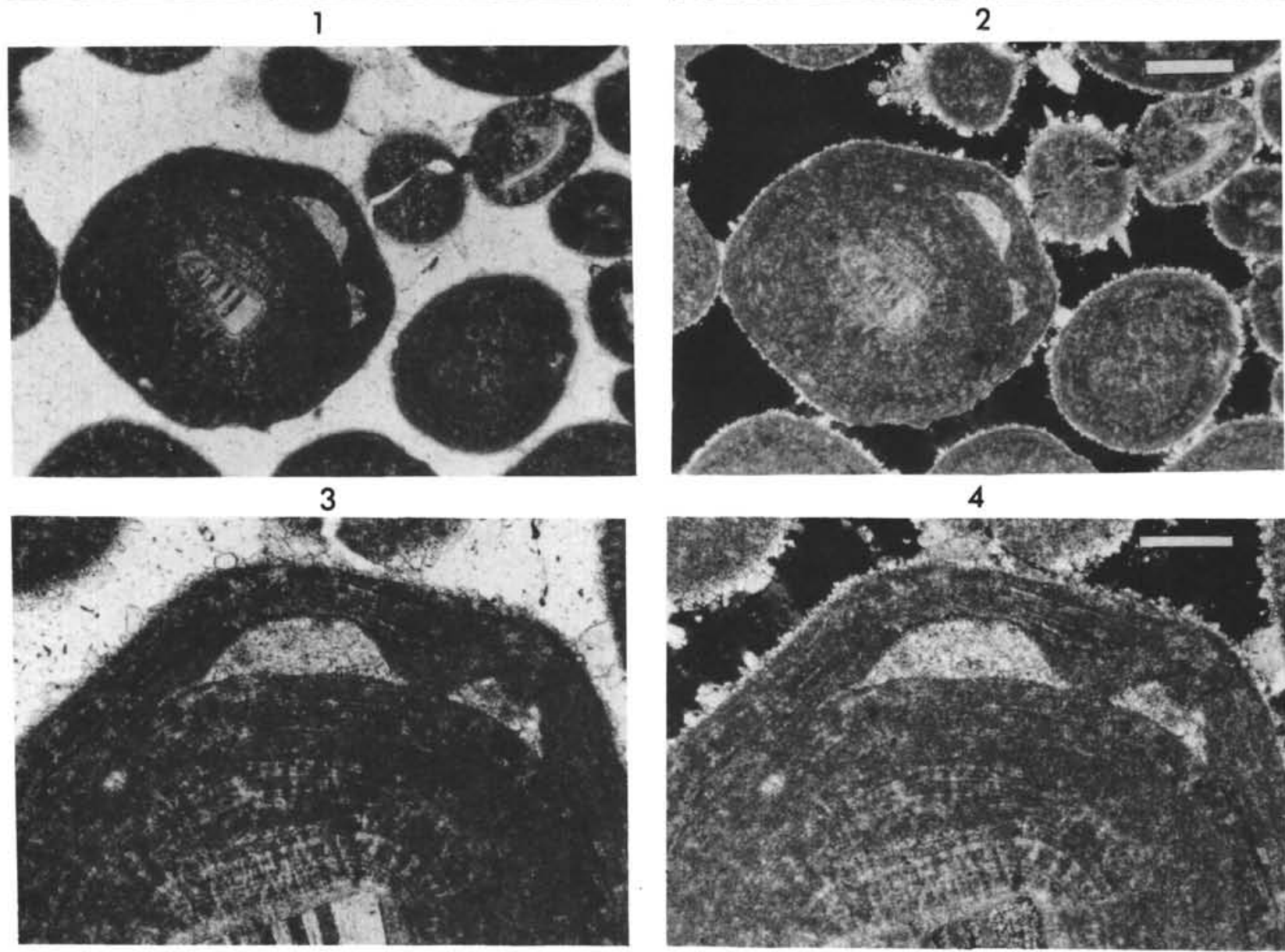

\section{4}

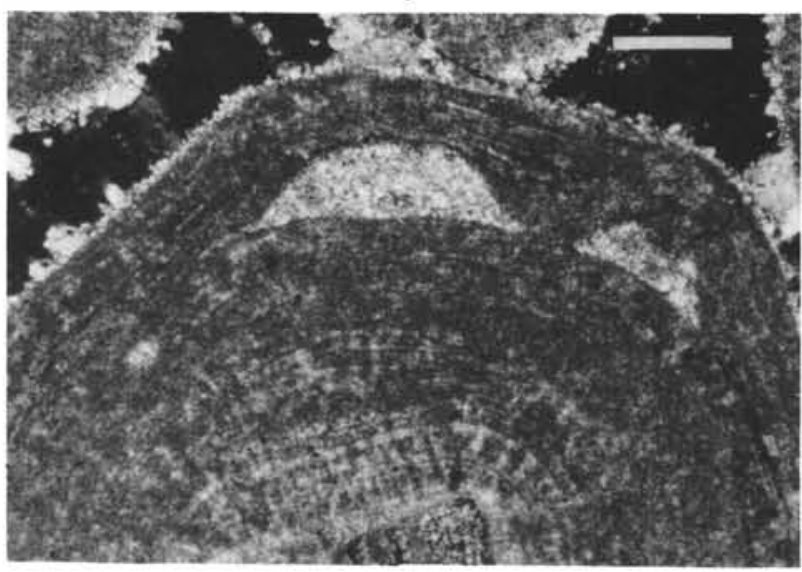

6 


\section{PLATE 4}

\section{Scanning Electron Microscope Photos}

Figures 1.4 Artificially broken ooid displaying partially open internal cavity. Note coarseness of internal sparry cement as compared to the nannocrystals (up to $5 \mu$ in length) of recrystallized cortex. Cortex crystals show preferred radial orientation. Crystals of external rim cement are euhedral. Etched surface (1 min in diluted $\mathrm{HCl})$.

1. Magnification $\times 200$ (bar is $100 \mu)$.

2. Magnification $\times 500$ (bar is $40 \mu$ ).

3. Magnification $\times 2000$ (bar is $10 \mu$ ).

4. Magnification $\times 5000$ (bar is $4 \mu$ ).

Figures 5,6 Ooid cortex composed of elongate, radially oriented calcite enveloped by euhedral external cement. Elongate crystals appear to be not longer than $6 \mu$ and not broader than about $1 \mu$. External rim cement (euhedral crystals) are 10 to $15 \mu$ in length. Etched surface $(1 \mathrm{~min}$ in diluted $\mathrm{CHI})$.

5. Magnification $\times 2000$ (bar is $10 \mu$ ).

6. Magnification $\times 5000$ (bar is $4 \mu$ ). 


\section{PLATE 4}
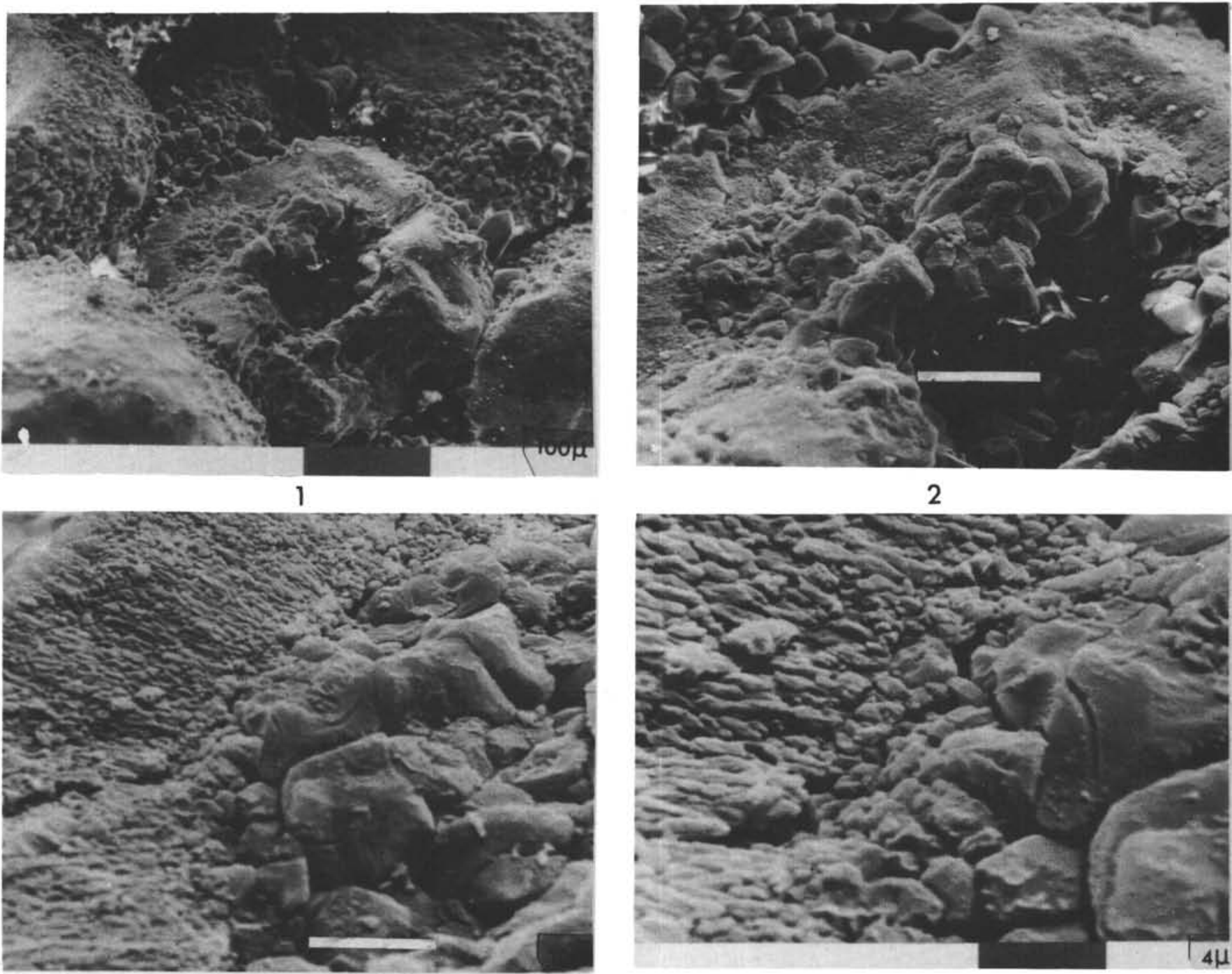

2

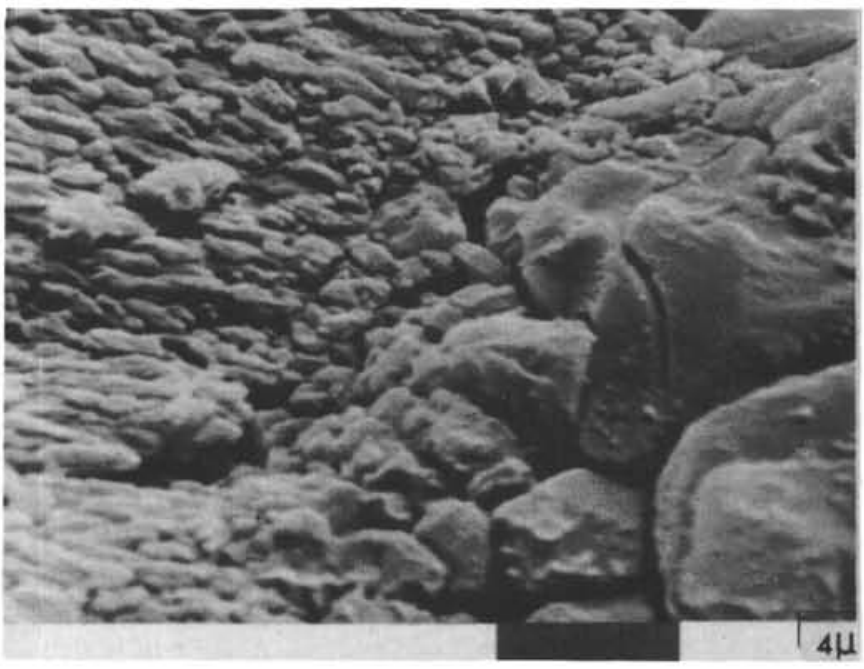

3
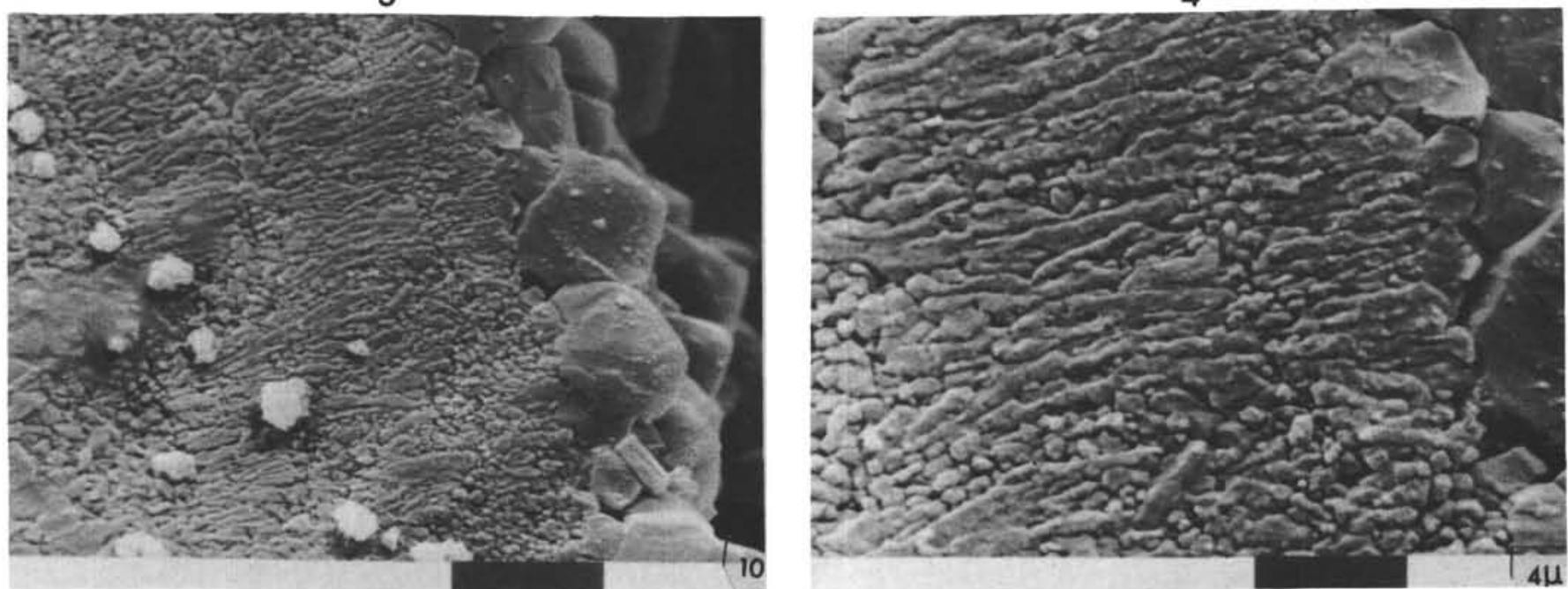
PLATE 5

Scanning Electron Microscope Photos

Figures 1-4 Broken ooid displaying internal sparry cement. Cortex made up of anhedral nannocrystals of calcite lacking preferred orientation. Etched surface $(1 \mathrm{~min}$ in diluted $\mathrm{HCl}$ ).

1. Magnification $\times 100$ (length of bar of $200 \mu$ ).

2. Magnification $\times 500$ (length of bar is $40 \mu$ ).

3. Magnification $\times 2000$ (length of bar is $10 \mu$ ).

4. Magnification $\times 10,000$ (length of bar is $2 \mu$ ).

Figures 5, 6 Cross-section of single laminae of ooid cortex consisting of anhedral nannofossil crystals of calcite less than $1 \mu$ in diameter. Crystals appear not to be in close contact. Indistinct radial orientation of nannofossil crystals in parts of lamina. Etched surface (1 min in diluted $\mathrm{HCl}$ ).

5. Mangification $\times 1000$ (length of bar is $20 \mu$ ).

6. Magnification $\times 5000$ (length of bar is $4 \mu$ ). 


\section{PLATE 5}
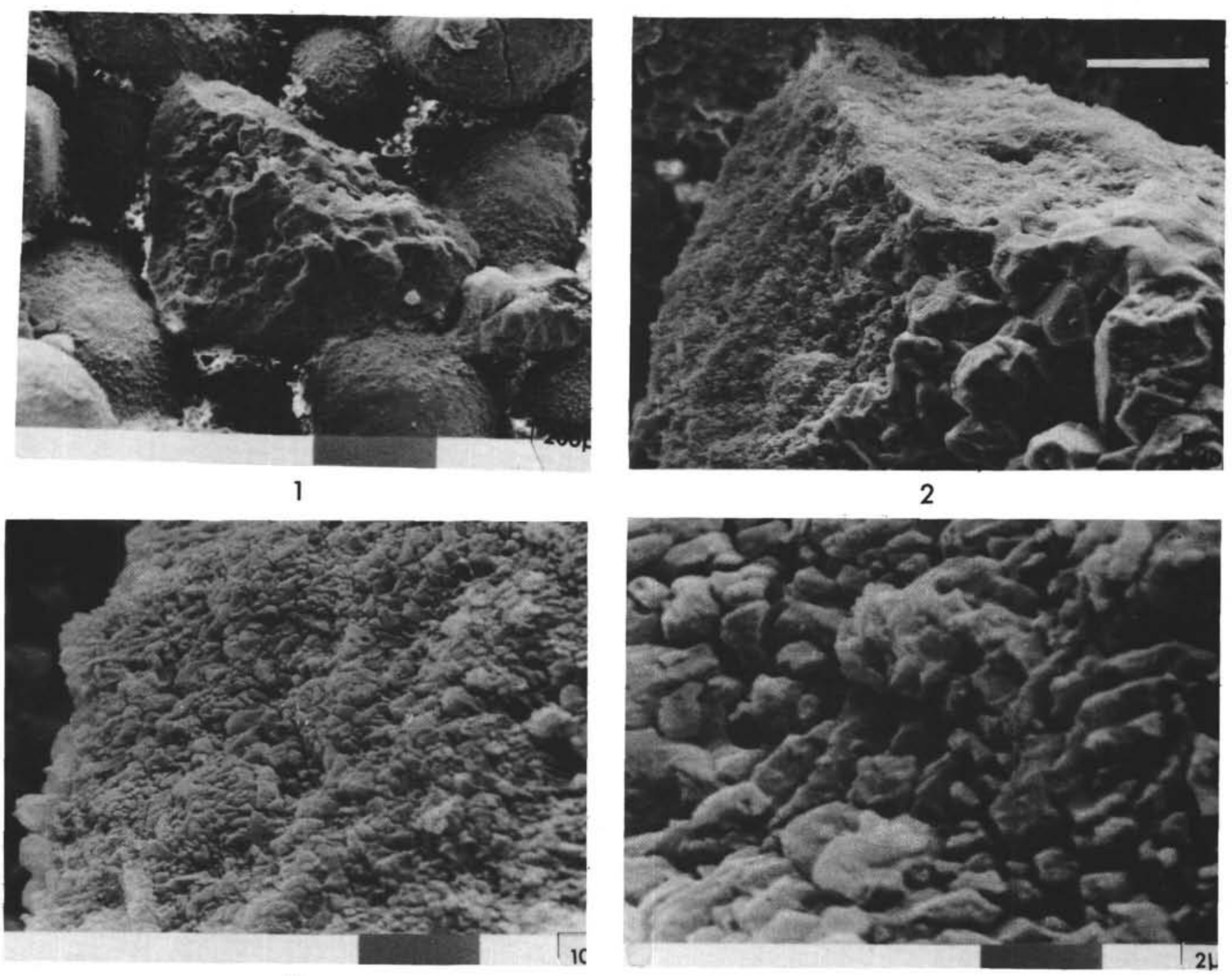

3

4
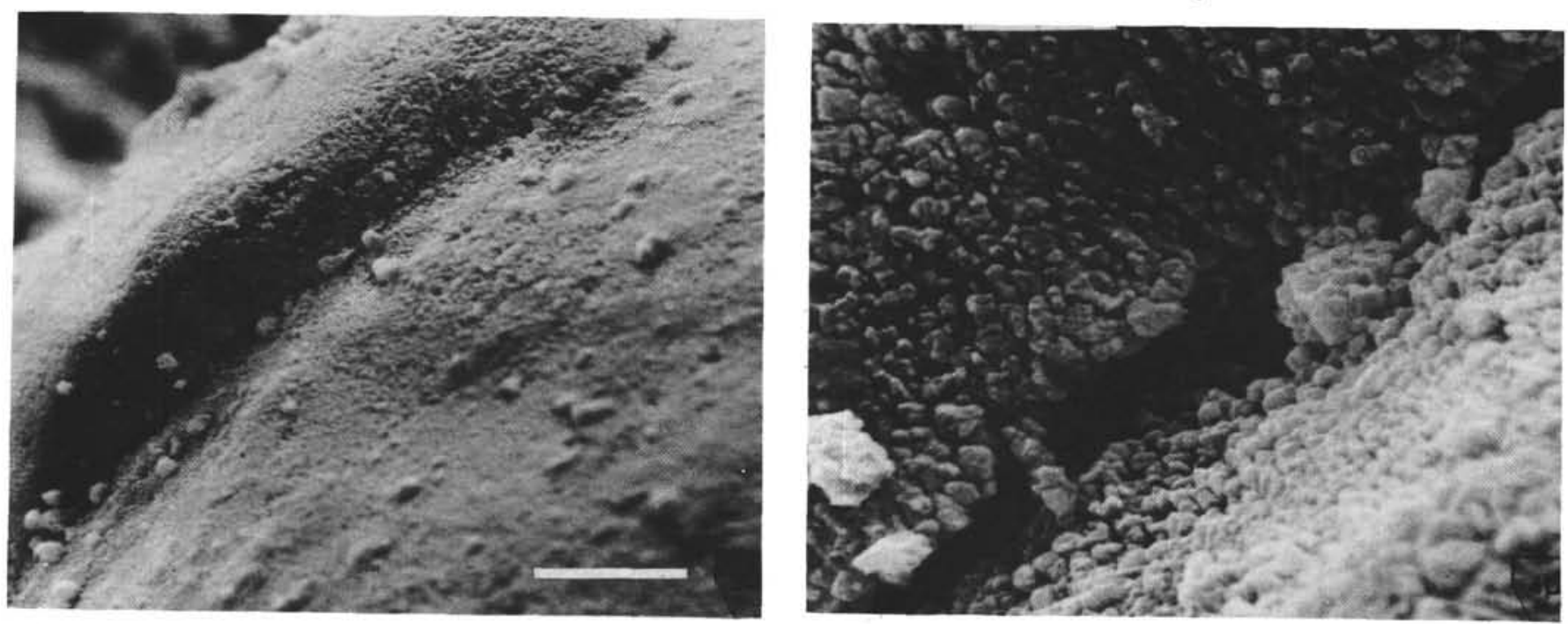


\section{PLATE 6}

\section{Scanning Electron Microscope Photos}

Strongly etched ( $3 \mathrm{~min}$ in diluted $\mathrm{HCl}$ ) surface of broken ooid. Undissolvable concentric light lamina of unknown composition in center of cortex (? organic matter). Its seemingly crystalline surface could be a replica of the surface of adjacent calcite laminae. This would also hold for the clusters of light material in the inner part of the cortex. Calcite nanno-crystals are either radially oriented (lamina on top of light lamina) or unoriented (inside of light lamina). Nucleus has been dissolved and partially replaced by coarse internal sparry calcite cement.

Figure 1 Magnification $\times 200$ (length of bar is $100 \mu$ ).

Figure 2 Magnification $\times 500$ (length of bar if $40 \mu$ ).

Figure 3 Magnification $\times 1000$ (length of bar is $20 \mu$ ).

Figure 4 Magnification $\times 2000$ (length of bar is $10 \mu$ ).

Figure 5 Magnification $\times 5000$ (length of bar is $4 \mu$ ).

Figure 6 Magnification $\times 10,000$ (length of bar is $2 \mu$ ). 
PLATE 6

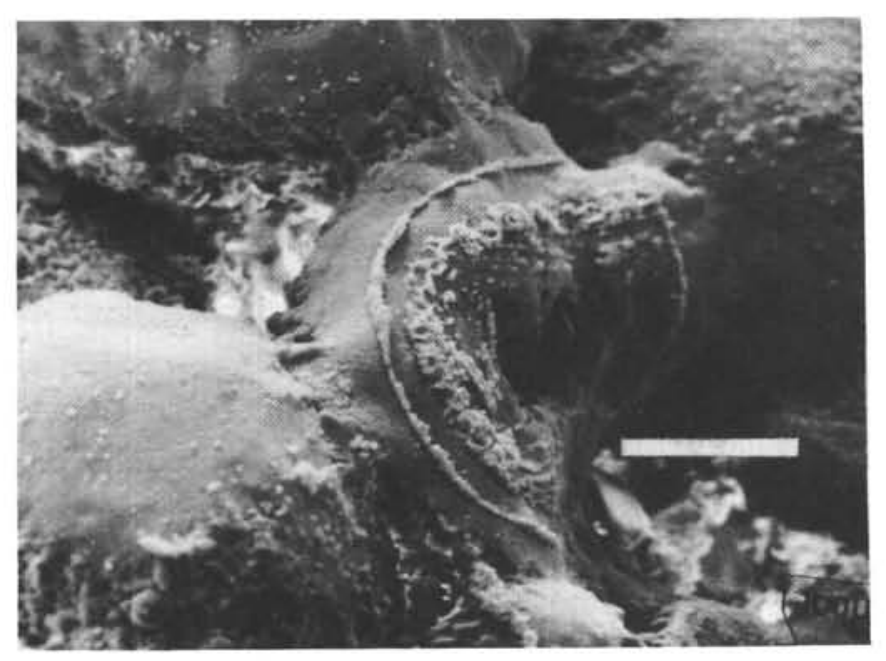

1

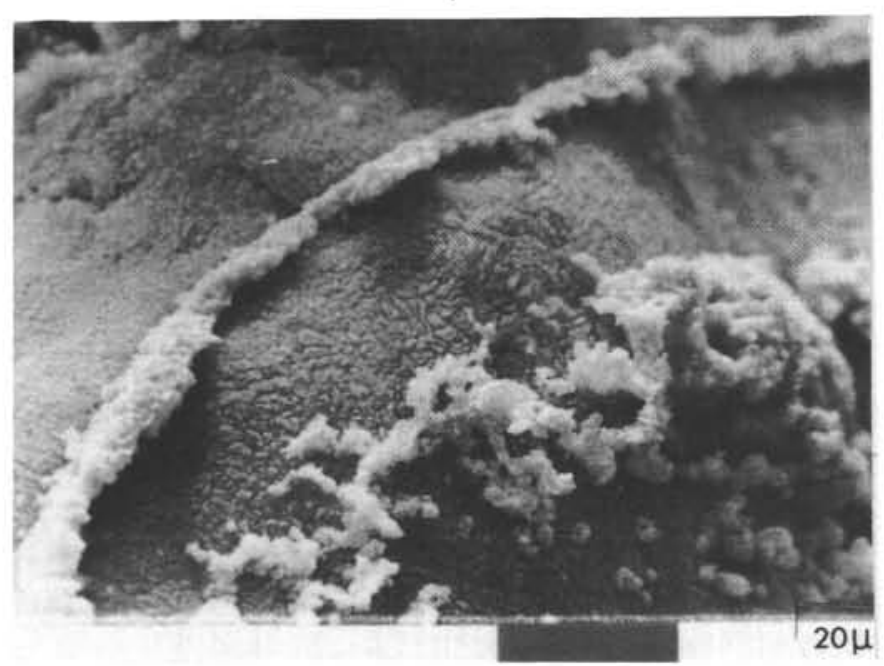

3

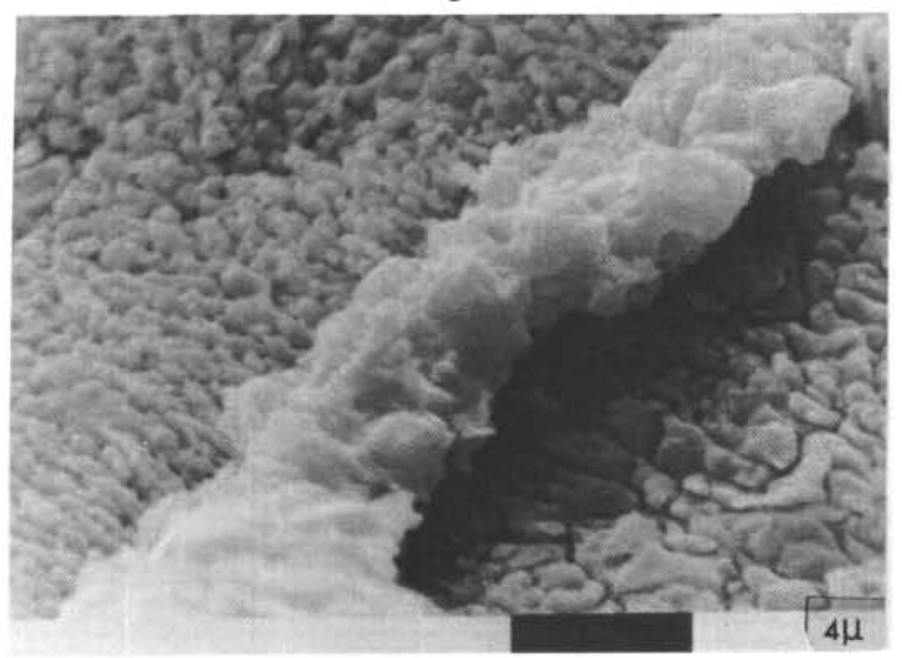

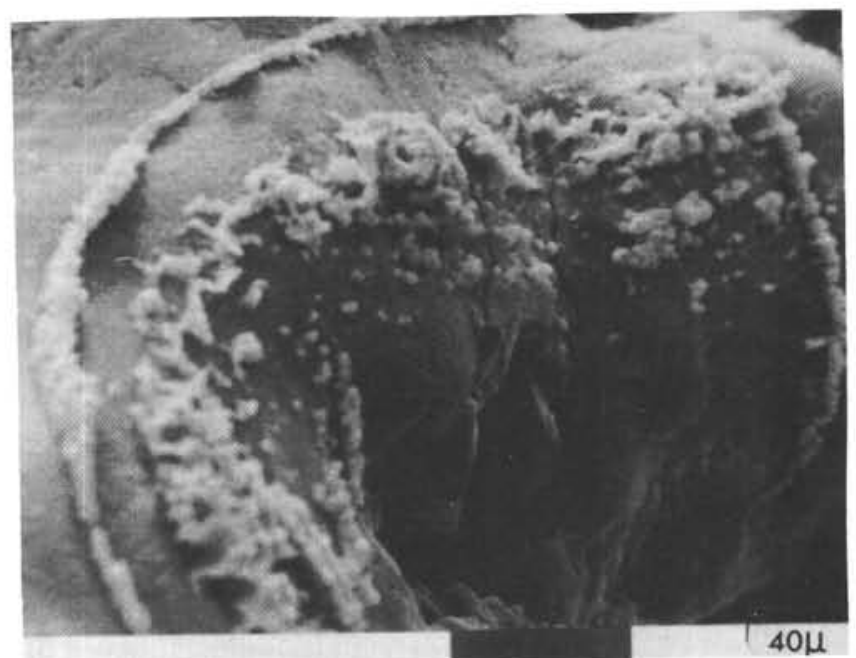

2

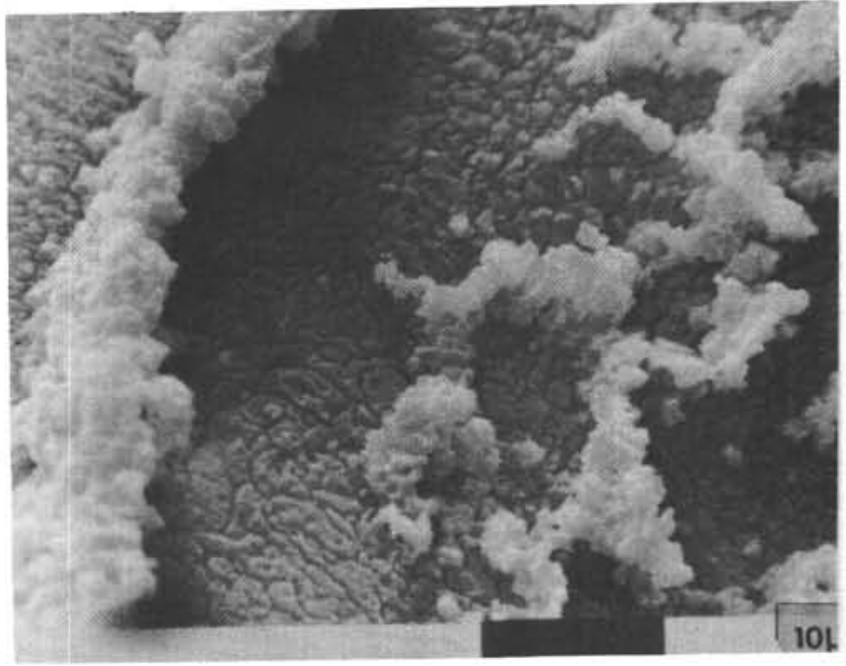

4

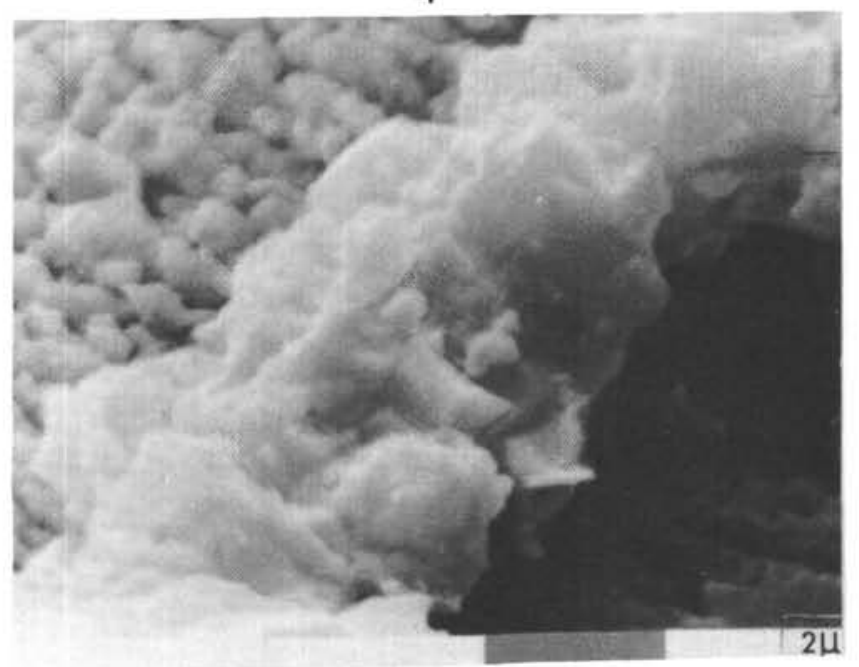

6 


\section{PLATE 7}

Figure 1 Internal dissolution of aragonite in skeletal fragment (mollusc) leaves micritic rim which is partially cemented by internal sparry calcite.

Figure 2 Crossed nicols (length of bar is $250 \mu$ ).

Figure 3 Strongly micritized rim of skeletal fragment. Internal dissolution of unmicritized center followed by internal cementation. Sparry calcite cement is coarsest in center where some open pore space is left.

Figure 4 Crossed nicols (length of bar is $100 \mu$ ).

Figure 5 Partial dissolution of skeletal fragment (mollusc). Only top part of the fragment enclosed in the micritic envelope was dissolved. Open space partially filled by sparry calcite cement. Cross-lamellar structure preserved in undissolved part of biogenic fragment.

Figure 6 Crossed nicols (absence of sparry rim cement on some grains caused by grinding). (Length of bar is $250 \mu$ ). 
PLATE 7

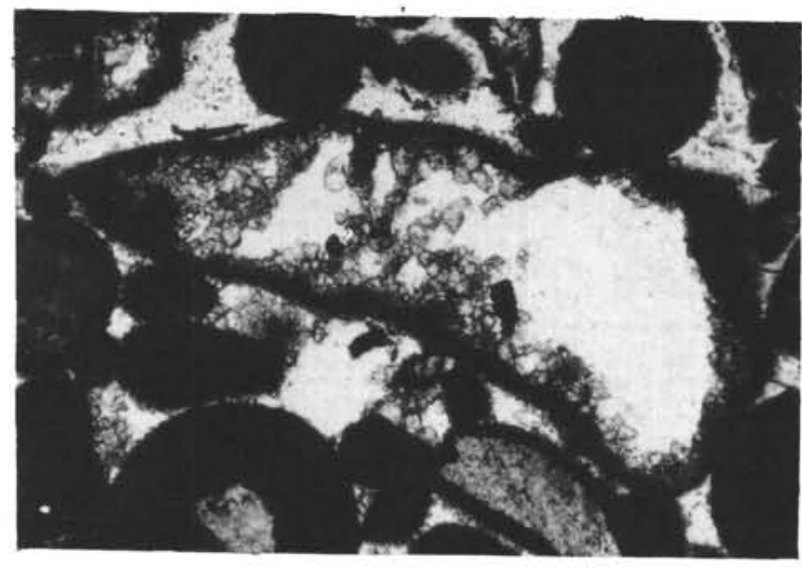

1

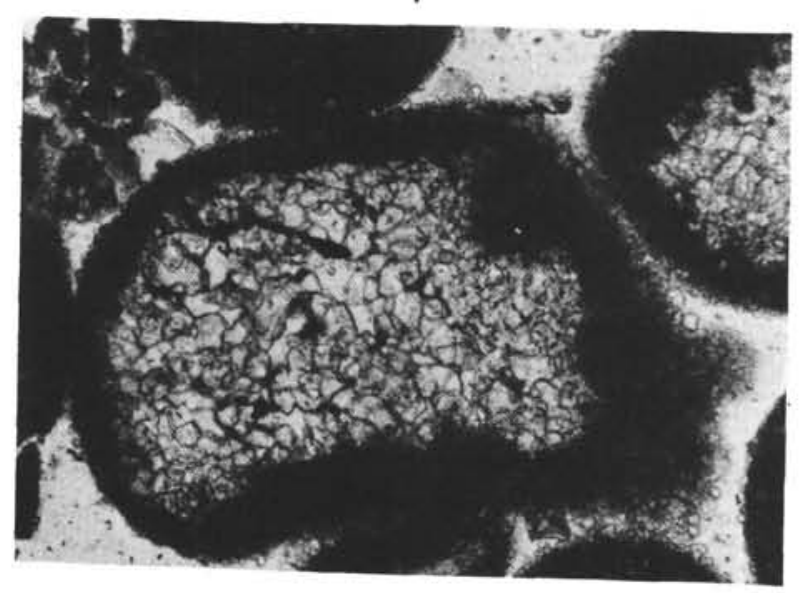

3

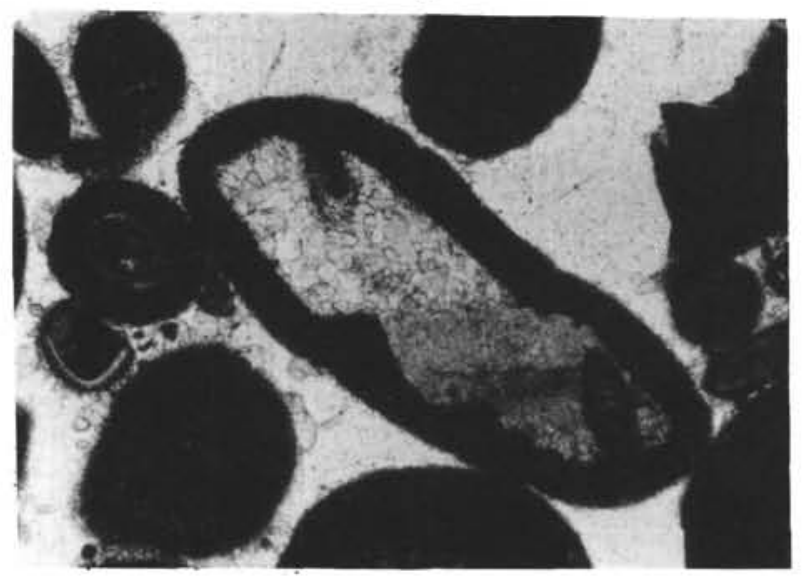

5

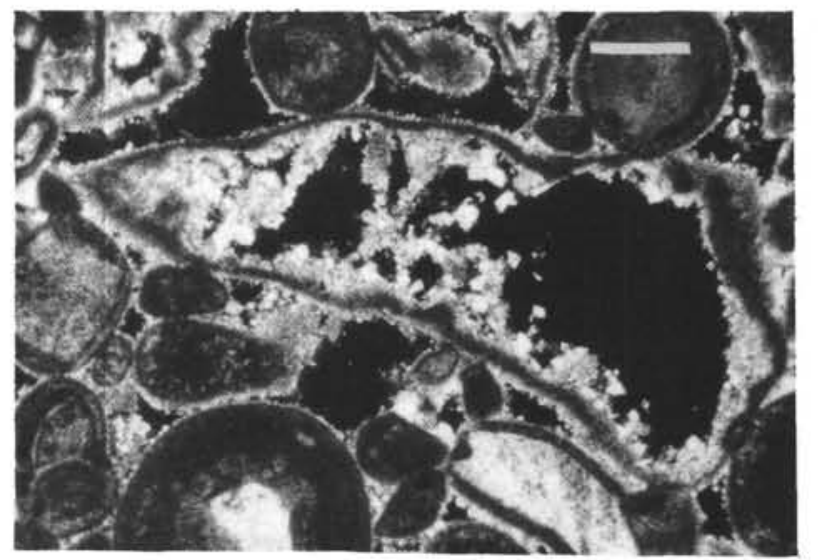

2

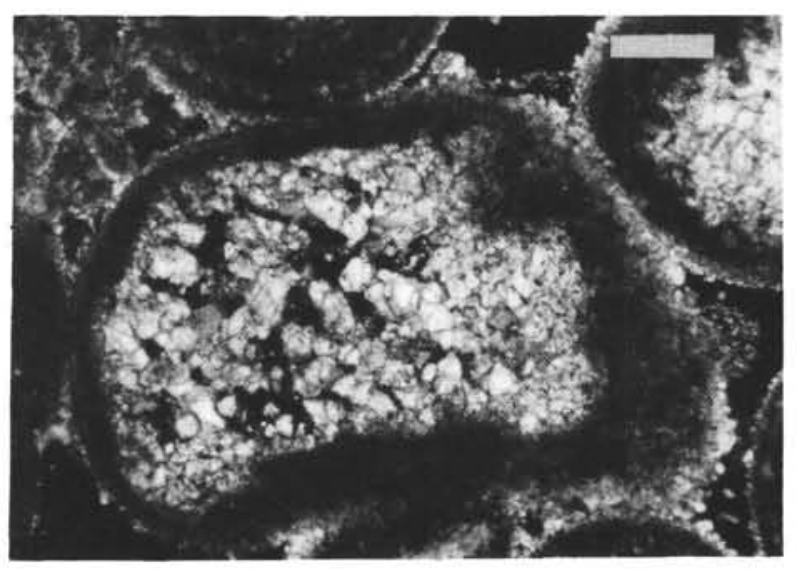

4

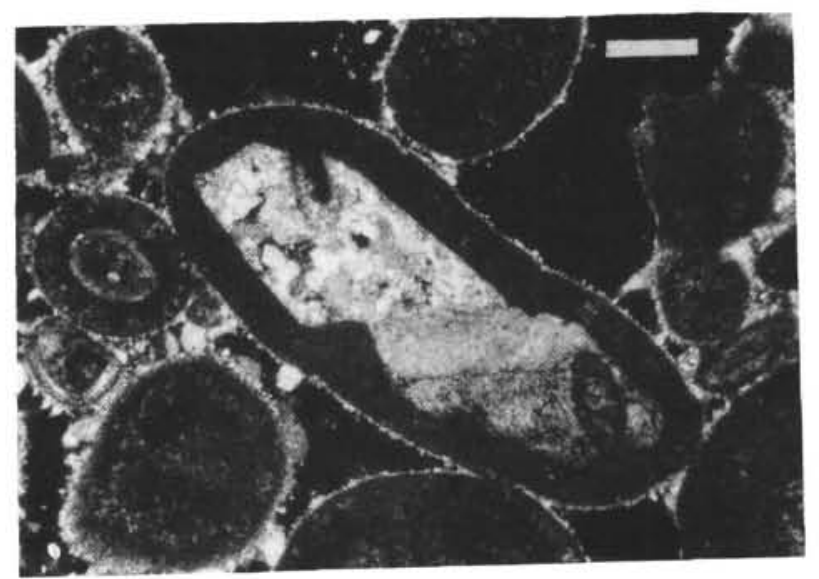

6 


\section{PLATE 8}

\section{Echinoderm Rim Cement}

Figure 1

Syntaxial overgrowth (about $120 \mu$ thick) on echinoderm spine (cross-section). Note absence or limitation in size of euhedral rim cement on other framework grains partially enclosed in the syntaxial rim of the echinoderm fragment. Only where these grains are more than about $50 \mu$ away from the echinoderm spine, their own rim cement grows to its normal size.

Figure 2 Crossed nicols (length of bar is $400 \mu$ ).

Figure 3 Syntaxial overgrowth on fragment of echinoderm (broken arm plate). Note that the fragment is only very slightly micritized at its outer margin (compare Figs. 1 and 2). Framework of strongly micritized ooids.

Figure 4 Crossed nicols (length of bar is $250 \mu$ ).

Figure $5 \quad$ Echinoderm-spine coated by thick laminated micrite envelope. Formation of single-crystal overgrowth. Micrite development probably not due to microborers.

Figure 6 Crossed nicols (length of bar is $100 \mu$ ). 
PLATE 8

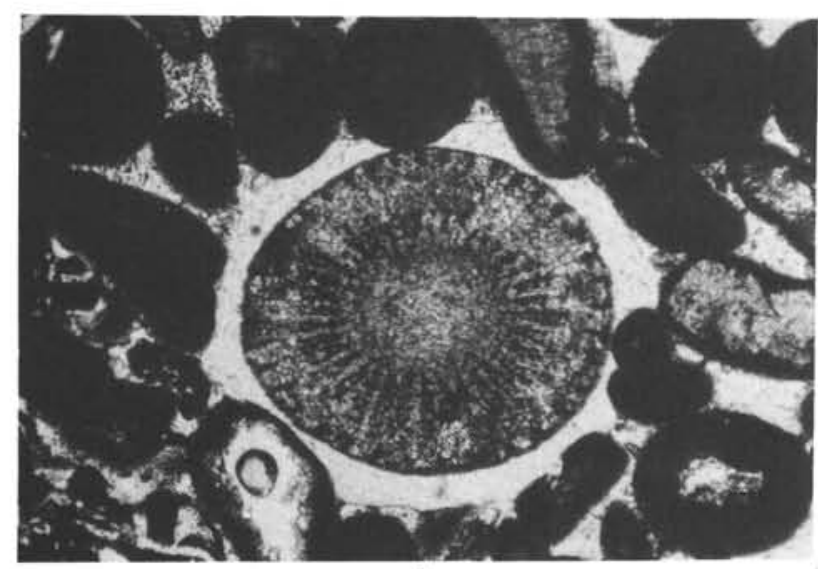

1

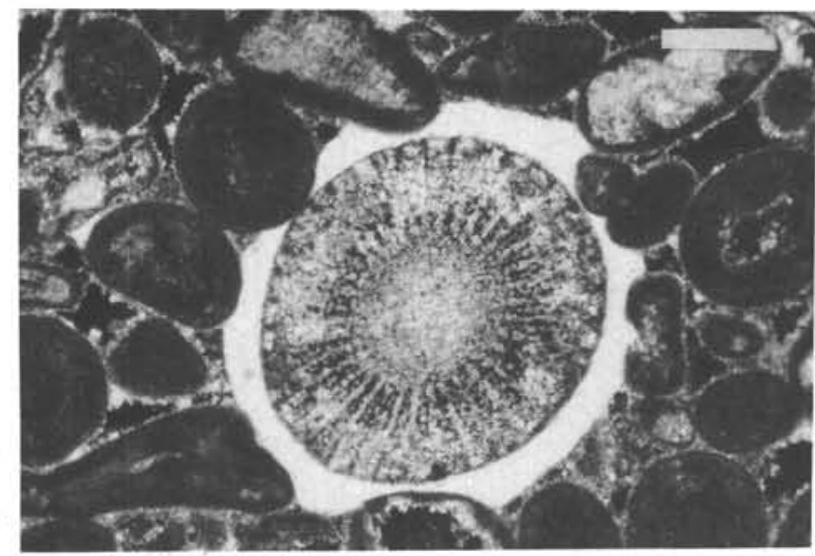

\section{2}

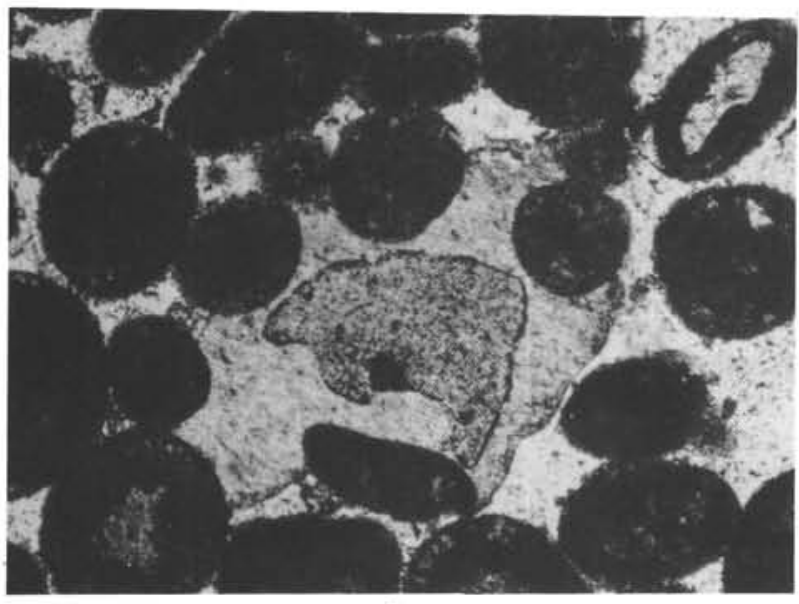

3

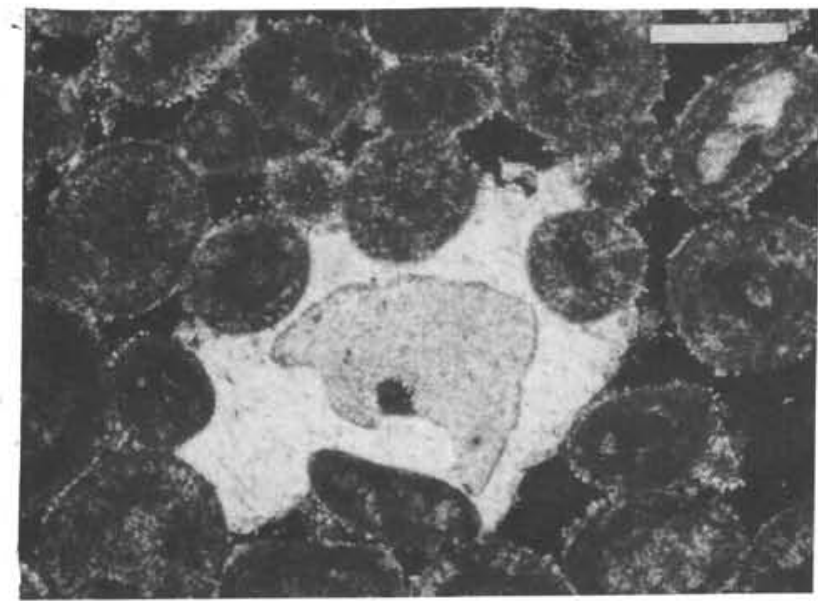

4

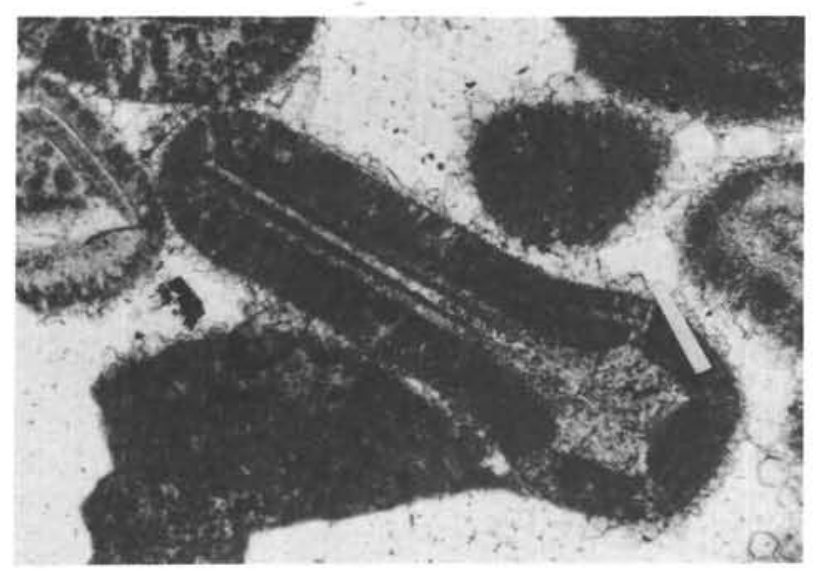

5

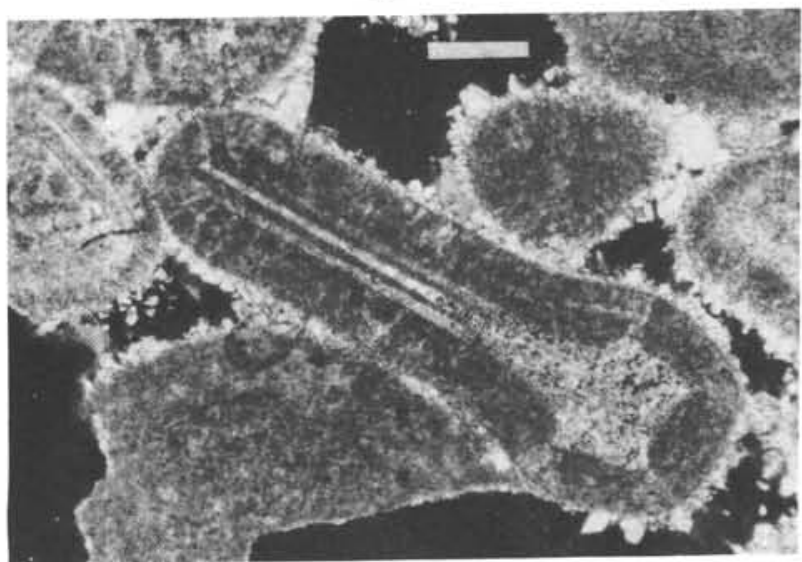

6 


\section{PLATE 9}

Figure 1 Lithoclast of oolite. This fragment is fully cemented in contrast to the oolite studied.

Figure 2 Crossed nicols (length of bar is $250 \mu$ ).

Figure 3 Lithoclast of basalt with feldspar phenocrysts and micrite rim.

Figure $4 \quad$ Crossed nicols (length of bar is $250 \mu$ ).

Figure 5 Mollusc fragment with strongly micritized rim. Micritized rim is faintly laminated and possibly not due to microboring. Thickness of rim where cut normal to grain surface: $50 \mu$. Note strongly micritized ooids and pellet.

Figure 6 Crossed nicols. Note minor amounts of external cement (length of bar is $100 \mu$ ). 
PLATE 9

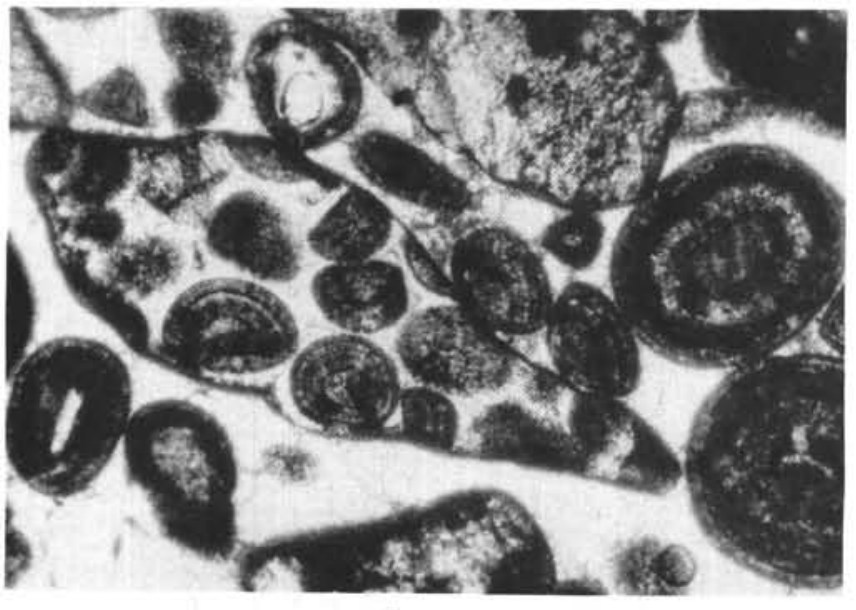

1

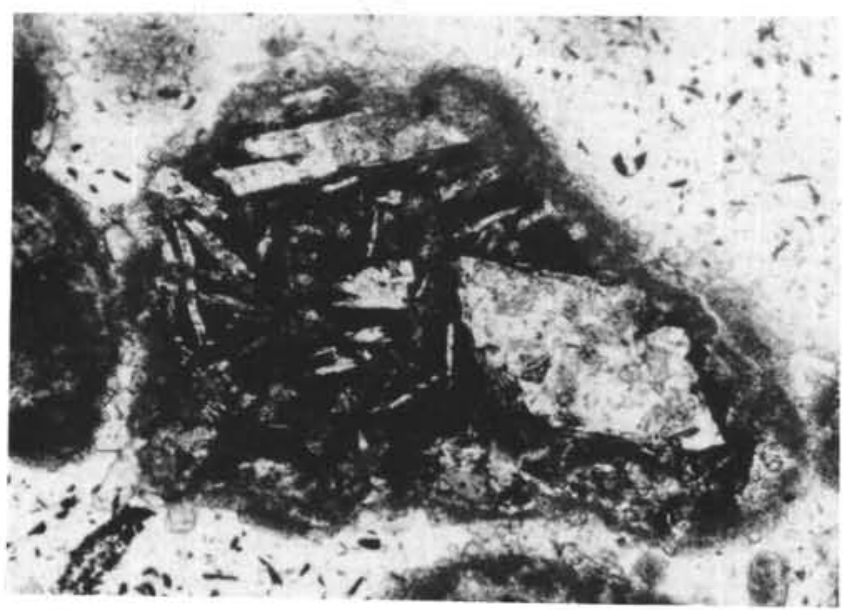

3

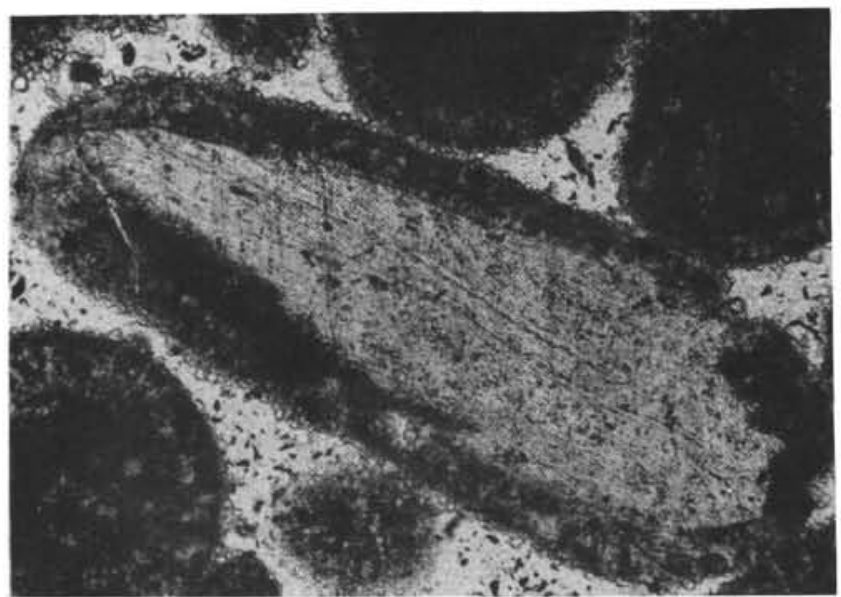

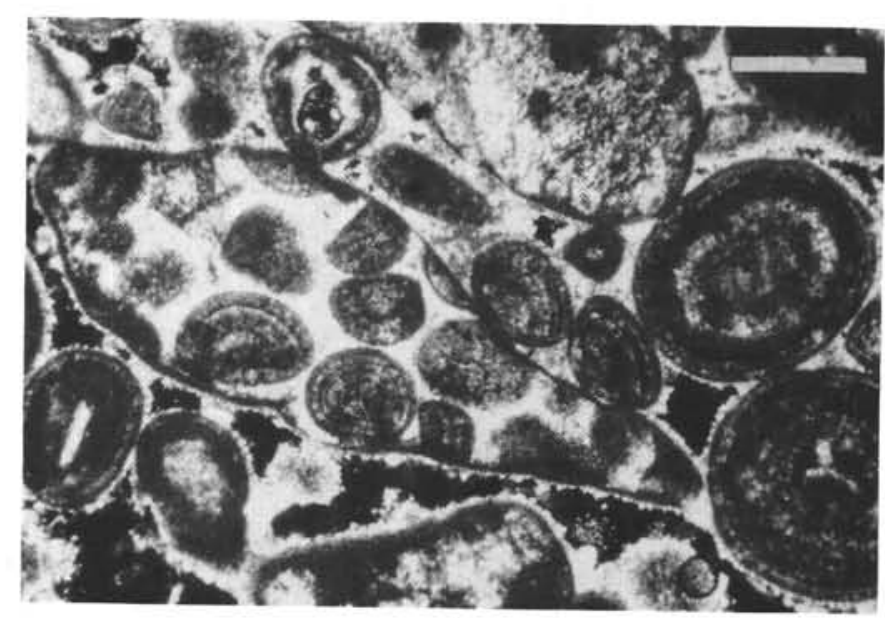

2

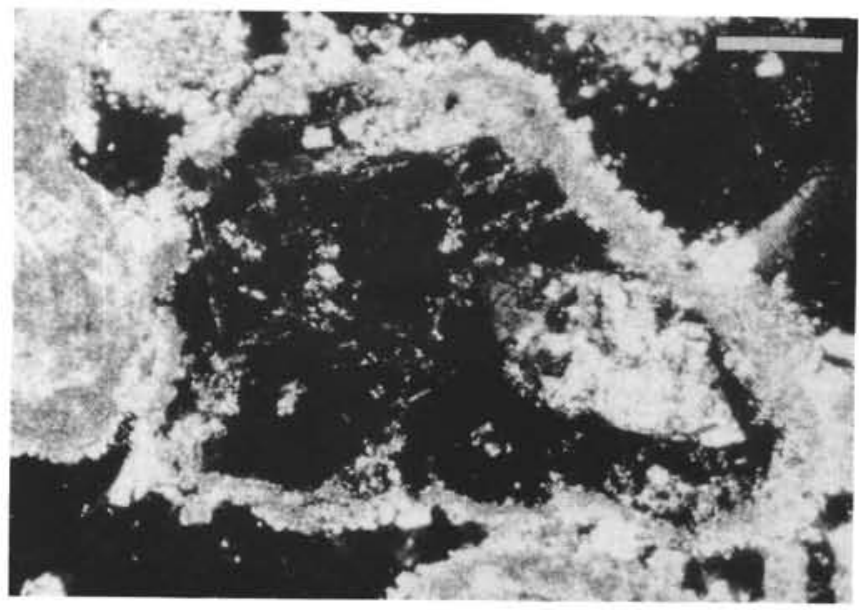

4

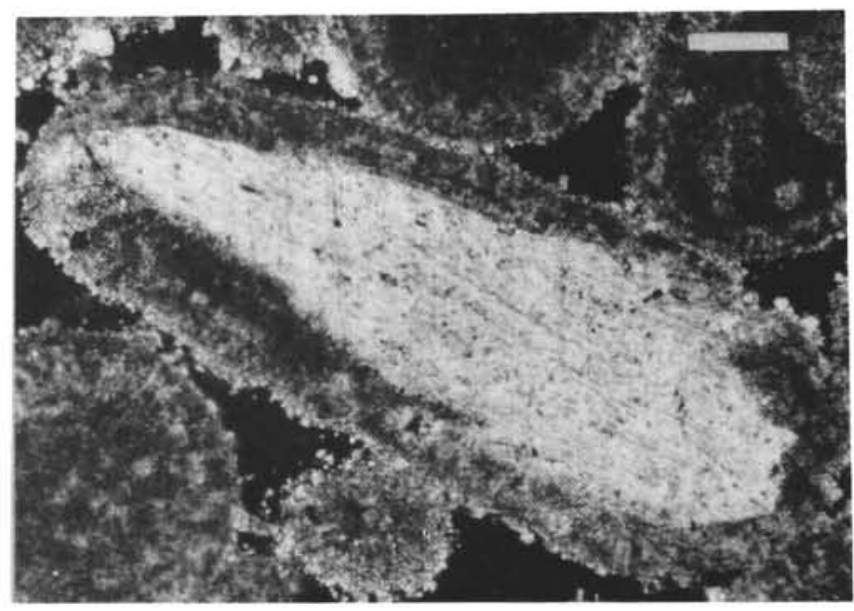

6 